\title{
Flood of April 2007 in New Hampshire
}

By Robert H. Flynn

Prepared in cooperation with the Federal Emergency Management Agency

Scientific Investigations Report 2008-5120

U.S. Department of the Interior

U.S. Geological Survey 


\title{
U.S. Department of the Interior DIRK KEMPTHORNE, Secretary
}

\author{
U.S. Geological Survey \\ Mark D. Myers, Director
}

U.S. Geological Survey, Reston, Virginia: 2008

For product and ordering information:

World Wide Web: http://www.usgs.gov/pubprod

Telephone: 1-888-ASK-USGS

For more information on the USGS — the Federal source for science about the Earth, its natural and living resources, natural hazards, and the environment:

World Wide Web: http://www.usgs.gov

Telephone: 1-888-ASK-USGS

Any use of trade, product, or firm names is for descriptive purposes only and does not imply endorsement by the U.S. Government.

Although this report is in the public domain, permission must be secured from the individual copyright owners to reproduce any copyrighted materials contained within this report.

Suggested citation:

Flynn, R.H., 2008, Flood of April 2007 in New Hampshire: U.S. Geological Survey Scientific Investigations Report 2008-5120, 53 p. 


\section{Acknowledgments}

The author would like to thank Stephen Doyon from the New Hampshire Department of Environmental Services (NHDES) for providing peak-stage and peak-discharge data from the streamgages that NHDES operates, and David Knowles from the Federal Emergency Management Agency for providing review comments on this report. The author would like to express appreciation to U.S. Geological Survey staff-Kenneth Toppin, Scott Olson, Chandlee Keirstead, Richard Kiah, Sanborn Ward, Heather Sirotnak and Glenn Berwickwho assisted with collection and analysis of the data in this report; and to Scott Olson and Gene Parker, who provided technical reviews of this report. 



\section{Contents}

Abstract

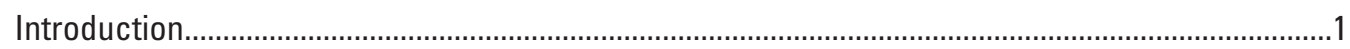

Description of Study Area ...........................................................................................

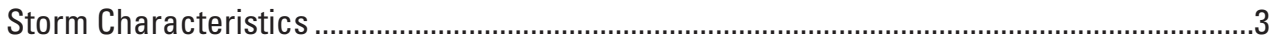

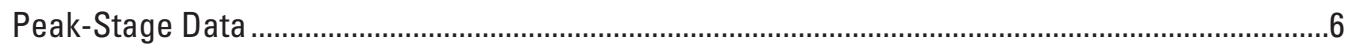

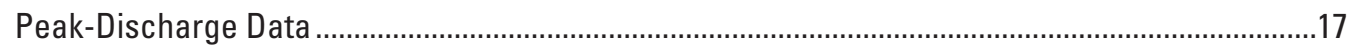

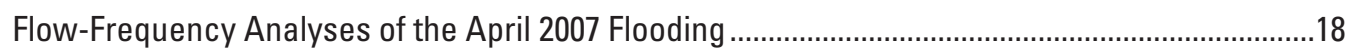

Determination of the April 2007 Flood Discharge by Indirect Methods at Ungaged Sites..............24

Comparison of the April 2007 Flood Data to Flood-Insurance Studies ............................................26

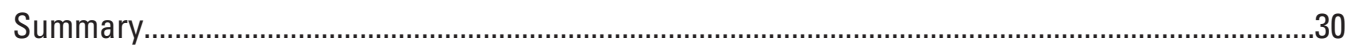

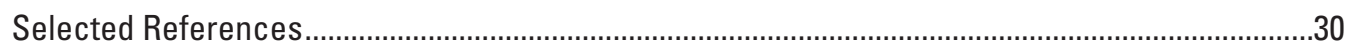

Appendix 1. HEC-RAS Model Calibrations to Estimate the April 2007 Flood-Peak Discharge from

High-Water-Mark Data Collected for the Lamprey, Souhegan, and Suncook Rivers.........39

\section{Figures}

1. Map showing counties included in the Presidential Disaster Declarations of April 27 and May 10, 2007

2A-3. Screenshots showing-

2A. The 1-day observed precipitation totals ending on April 16, 2007, New Hampshire and Vermont.

2B. The 1-day observed precipitation totals ending on April 17, 2007, New Hampshire and Vermont.

2C. The 1-day observed precipitation totals ending on April 18, 2007, New Hampshire

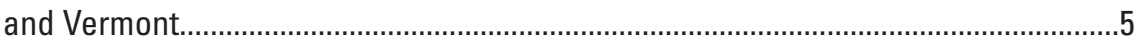

3. The April 2007 monthly observed precipitation, New Hampshire and Vermont........5

4A-5. Maps showing-

4A. Location of U.S. Geological Survey streamgage sites and indirect dischargemeasurement sites having peak stage and discharge data for the April 2007 flood in Hillsborough County, New Hampshire.

4B. Location of U.S. Geological Survey streamgage sites and indirect dischargemeasurement sites having peak stage and discharge data for the April 2007 flood in Rockingham County, New Hampshire.

4C. Location of U.S. Geological Survey streamgage sites and indirect dischargemeasurement sites having peak stage and discharge data for the April 2007 flood in Merrimack County, New Hampshire

4D. Location of U.S. Geological Survey streamgage sites having peak stage and discharge data for the April 2007 flood in Belknap County, New Hampshire..........13

4E. Location of U.S. Geological Survey streamgage sites having peak stage and discharge data for the April 2007 flood in Strafford County, New Hampshire

4F. Location of U.S. Geological Survey streamgage sites having peak stage and discharge data for the April 2007 flood in Grafton County, New Hampshire

4G. Location of U.S. Geological Survey streamgage sites having peak stage and discharge data for the April 2007 flood in Carroll County, New Hampshire 
5. Recurrence intervals for the April 2007 flood at streamgages in Hillsborough, Rockingham, Merrimack, Belknap, Strafford, Grafton, and Carroll Counties in New Hampshire

\section{Tables}

1. Description of streamgages used in the April 2007 flood investigation, central and southern New Hampshire

2. Peak-stage data and peak-discharge data during the April 2007 flood at 57 streamgage sites in central and southern New Hampshire.

3. Flow-frequency data and recurrence-interval estimates for 57 streamgages during the April 2007 flood in central and southern New Hampshire.

4. Flow-frequency data and recurrence-interval estimates by indirect methods for four ungaged sites during the April 2007 flood in central and southern New Hampshire......25

5. Flood-insurance study data for selected streamgage sites in central and southern New Hampshire

6. High-water-mark data used in the determination of April 2007 flood discharge by indirect methods for four ungaged sites in central and southern New Hampshire

\section{Conversion Factors and Datum}

\begin{tabular}{lcl}
\hline \multicolumn{1}{c}{ Multiply } & By & \multicolumn{1}{c}{ To obtain } \\
\hline & Length & \\
\hline inch (in.) & 2.54 & centimeter $(\mathrm{cm})$ \\
inch (in.) & 25.4 & millimeter $(\mathrm{mm})$ \\
foot (ft) & 0.3048 & meter $(\mathrm{m})$ \\
mile (mi) & 1.609 & kilometer $(\mathrm{km})$ \\
\hline & Area & \\
\hline square mile $\left(\mathrm{mi}^{2}\right)$ & 2.590 & square kilometer $\left(\mathrm{km}^{2}\right)$ \\
\hline & Flow rate & \\
\hline cubic foot per second $\left(\mathrm{ft}^{3} / \mathrm{s}\right)$ & 0.02832 & cubic meter per second $\left(\mathrm{m}^{3} / \mathrm{s}\right)$ \\
\hline
\end{tabular}

Horizontal coordinate information is referenced to the North American Datum of 1927 (NAD 27).

Vertical coordinate information is referenced to the National Geodetic Vertical Datum of 1929 (NGVD 29) and North American Vertical Datum of 1988 (NAVD 88). 


\title{
Flood of April 2007 in New Hampshire
}

\author{
By Robert H. Flynn
}

\section{Abstract}

During April 16-18, 2007, central and southeastern New Hampshire experienced severe flooding as a result of up to 7 inches of rainfall from a storm that stalled off the New England coast. As a result of the flooding, a Presidential Disaster Declaration was issued on April 27, 2007. On that day, disaster declarations were announced for Grafton, Hillsborough, Merrimack, Rockingham, and Strafford Counties. On May 10, 2007, Belknap County was added to the disaster declaration.

Following the flooding, the U.S. Geological Survey, in a cooperative investigation with the Federal Emergency Management Agency, determined the peak stages, peak discharges, and recurrence-interval estimates of the April 2007 flood at 57 streamgages and 4 ungaged sites in and adjacent to the counties named in the disaster declaration. Data from flood-insurance studies published by the Federal Emergency Management Agency also were compiled for each streamgage site for comparison purposes.

The peak discharges during the April 2007 flood were the highest ever recorded at five long-term (more than 10 years of record) streamgage sites on the New HampshireSalmon Falls River at Milton, Cocheco River near Rochester, Oyster River near Durham, Contoocook River at Peterborough, and South Branch Piscataquog River near Goffstown. In addition, peak discharges equaled or exceeded a 100-year recurrence interval at 10 streamgages and a 50-year recurrence interval at 16 streamgages. The most severe flooding occurred in Rockingham, Strafford, Merrimack, and Hillsborough Counties.

\section{Introduction}

Major flooding in central and southern New Hampshire (fig. 1) from April 16 to 18, 2007, resulted in substantial damage to public and personal property. Homes and roads were damaged, and numerous residential areas were evacuated for several days. As a result of the widespread damage caused by the flooding, President George W. Bush issued a Presidential Disaster Declaration on April 27, 2007, for the counties of Grafton, Hillsborough, Merrimack, Rockingham, and Strafford in New Hampshire (fig. 1; Federal Emergency Management Agency, 2007). Belknap County in New Hampshire was added to the disaster declaration on May 10, 2007 (Federal Emergency Management Agency, 2007). In response to the disaster declaration, the U.S. Geological Survey (USGS), in cooperation with the Federal Emergency Management Agency (FEMA), measured or computed flood characteristics at 57 streamgages and 4 ungaged locations within and adjacent to the disaster areas.

The April 2007 flood is documented in this report through the presentation of flood data collected at 46 active and 11 discontinued streamgages and 4 ungaged locations in central and southern New Hampshire. The flood data include peak-stage data, peak-discharge data, flow-frequency curves, and estimates of flood-recurrence intervals at each streamgage. In addition, data were compiled from 20 town/city-wide and 3 county-wide FEMA flood-insurance studies for comparison purposes. The active streamgages include 37 operated by the USGS, 7 operated by the New Hampshire Department of Environmental Services (NHDES), and 2 operated by the U.S. Army Corps of Engineers (USACE). All 11 discontinued streamgages previously had been operated by the USGS. A description of each streamgage site included in this investigation is provided in table 1 (in back of report).

Although the April 16-18, 2007, storm produced less precipitation than either the October 1996 or May 2006 storm events, some streams in New Hampshire had higher discharges in the 2007 event. For example, on April 16, 2007, a peak discharge of $1,320 \mathrm{ft}^{3} / \mathrm{s}$ occurred at the Oyster River streamgage near Durham, N.H. Prior to this peak, the peak discharge of record at that station was $1,160 \mathrm{ft}^{3} / \mathrm{s}$ on October $21,1996$. The April 16-18, 2007, precipitation resulted in discharges that were the maximum for the period of record at 5 long-term (more than 10 years of record) streamgage sites in central and southern New Hampshire.

The primary difference between the flooding events of May 2006 and October 1996 was the antecedent ground conditions in May 2006 (National Oceanic and Atmospheric Administration, 2006b) that resulted in greater discharges during the May 2006 event at many streamgages. The primary difference between the April 2007 flooding event and the May 2006 and October 1996 events was the precipitation on top of snowpack that resulted in greater discharges during the April 2007 event at many streamgages. 


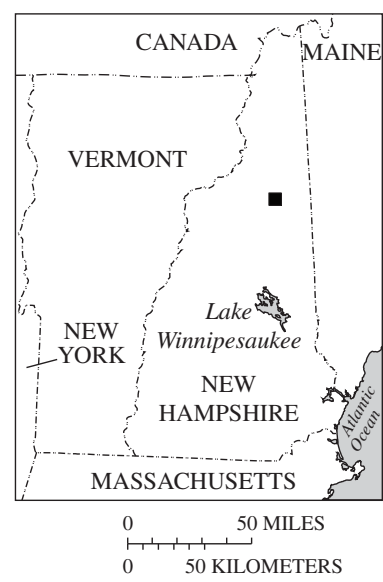

\section{EXPLANATION}

Designated counties

$\checkmark$ Public assistance

Disaster area

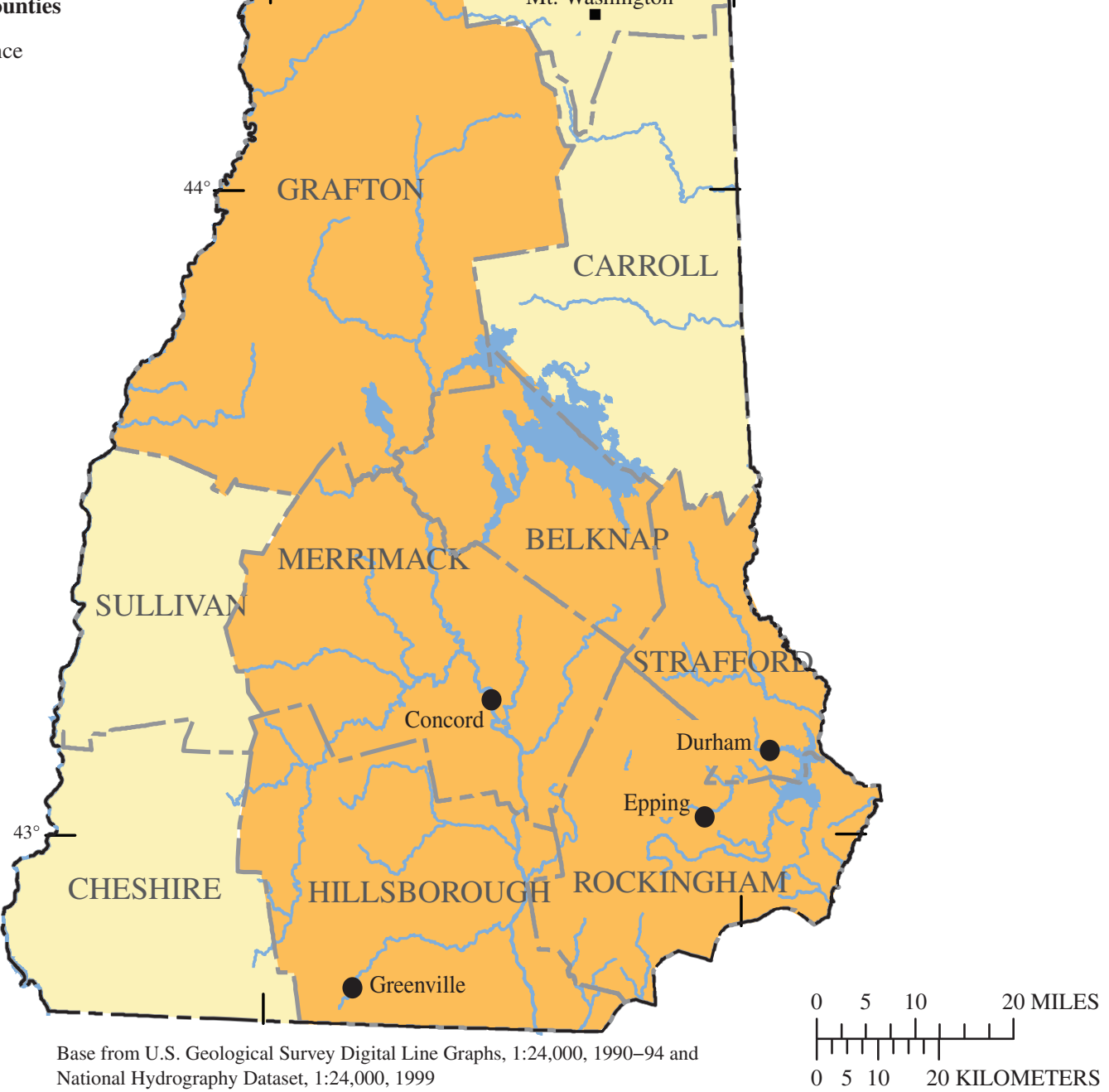

Figure 1. Counties included in the Presidential Disaster Declarations of April 27 and May 10, 2007. (FEMA-1695-DR, Federal Emergency Management Agency, 2007) 
The higher than normal precipitation from the April 2007 storm, which included precipitation on top of snowpack at higher elevations, downed trees, and wood debris in some rivers all contributed to the high flows and flooding in southern and central New Hampshire. In addition, an abnormally high spring tide along with a storm surge of nearly $3 \mathrm{ft}$ caused tidal flooding along portions of the seacoast (National Oceanic and Atmospheric Administration, 2007b), and the prolonged period of strong northeast winds caused a prolonged storm surge along the coastline (National Climate Data Center, 2007).

\section{Description of Study Area}

The six New Hampshire counties included in the disaster declaration (fig. 1) compose a land area of $5,245 \mathrm{mi}^{2}$ in the northeastern United States. Land elevations range from zero feet above the North American Vertical Datum of 1988 (NAVD 88) at Mean Lower Low Water (MLLW) at the seacoast to greater than $4,000 \mathrm{ft}$ above the NAVD 88 in the north-central part of New Hampshire. The climate of New Hampshire is humid. Precipitation is distributed fairly evenly across the state and averages about 43 in. per year except in regions that can receive additional precipitation due to elevation and snowfall. From 1971 to 2000, Mount Washington received an average of 101.9 in. of precipitation per year, while Concord received an average of 37.6 in. of precipitation (National Climate Data Center, 2008). The average (1971-2000) precipitation for April in Concord, N.H., was approximately 3.07 in. (National Climate Data Center, 2008).

\section{Storm Characteristics}

The precipitation that occurred from April 15 to 19, 2007, produced 6.54 in. of rainfall in the southeastern New Hampshire towns of Durham and Epping and 7.25 in. of rainfall in Greenville, N.H. - a town in the south-central part of the state (National Oceanic and Atmospheric Administration, 2007a). Because April 16, 2007, was the Patriot's Day holiday, the storm has since been referred to as the Patriot's Day storm. The rainfall began on Sunday, April 15, 2007; snow accumulated in many areas and changed to rain, at first along the coast then eventually inland and northward. In Concord, snow accumulated to a total melted precipitation of 1.26 in. (National Oceanic and Atmospheric Administration, 2007b) on April 15. The rainfall became heavy on Sunday, April 15, during the afternoon and overnight. By the morning of Monday, April 16, 3 to 5 in. of rain had fallen over much of southeastern New Hampshire (fig. 2A; Northeast River Forecast Center, 2007a), and 1 to $3 \mathrm{in.} \mathrm{had} \mathrm{fallen} \mathrm{across} \mathrm{much} \mathrm{of} \mathrm{the} \mathrm{remainder} \mathrm{of} \mathrm{the} \mathrm{state.} \mathrm{In}$ the mountains of New Hampshire, 3 to 11 in. of snow had fallen. Although the heaviest precipitation fell from Sunday afternoon into Monday afternoon, precipitation persisted through Tuesday, April 17 (fig. 2B; Northeast River Forecast Center, 2007a) and into Wednesday, April 18 (fig. 2C; Northeast River Forecast Center, 2007a). The heaviest rain fell on Monday, April 16 with 5.46 in. of rain recorded in Durham (National Oceanic and Atmospheric Administration, 2007a). The heavy rain combined with snow melt caused small rivers and streams in much of New Hampshire to flood. As with the May 2006 flood in New Hampshire (Olson, 2007), the most severe flooding occurred in Rockingham, Strafford, Merrimack, and Hillsborough Counties, although the smaller rivers in Rockingham County were the most severely affected (National Climate Data Center, 2007).

In addition to the rainfall, downed trees exacerbated flooding conditions in many rivers and streams. A barometricpressure gradient associated with the storm brought high winds to the region with a peak wind of $45 \mathrm{mph}$ recorded in Concord on April 16, 2007 (National Oceanic and Atmospheric Administration, 2007b). The damage observed in the hardest-hit areas was typical for wind gusts of 60 to $80 \mathrm{mph}$ (National Climate Data Center, 2007). Strong winds late on Sunday, April 15, and through most of Monday, April 16, were reported to have downed many trees, branches, and power lines. Damage from the wind was magnified because of the heavy rain that accompanied the wind and the soft, wet ground caused by the spring thaw. Due to high winds and antecedent wet-ground conditions, many trees were reported to have had their entire root systems lifted out of the ground (National Oceanic and Atmospheric Administration, 2007b).

As a result of the Patriot's Day storm of April 16-18, 2007, the month of April 2007 is the second wettest April (fig. 3) ever recorded in Concord, N.H. (National Oceanic and Atmospheric Administration, 2007b). A total of 7.22 in. of precipitation was recorded for Concord, which is just shy of the April record precipitation of 7.44 in. set in 1904. Snowfall also was abundant in April 2007 with 12 in. measured in Concord. This measurement tied the 1876 and 1879 levels as the 9th-snowiest April for Concord in the past 140 years of snowfall records (National Oceanic and Atmospheric Administration, 2007b). The largest snowfall in April 2007 for Concord totaled nearly 7.7 in. and fell during April 4-5 (National Oceanic and Atmospheric Administration, 2007b). All of the April snow for Concord fell over the first 15 days of the month (National Oceanic and Atmospheric Administration, 2007b). In March and April 2007, Concord received 29.2 in. of rainfall.

The total precipitation that occurred during April 15-19, 2007, in southeastern New Hampshire (6.54 in. in Durham) was approximately one-half of the $13 \mathrm{in}$. of precipitation that fell during October 20-22, 1996, across southeastern New Hampshire (National Oceanic and Atmospheric Administration, 1996). The total April 15-19, 2007, precipitation in southeastern New Hampshire was less than one-half of the up to 14 in. of precipitation that fell during May 11-15, 2006, across the coastal regions of New Hampshire (National Oceanic and Atmospheric Administration, 2006a) and approximately 60 percent of the up to $11 \mathrm{in}$. of precipitation that fell 


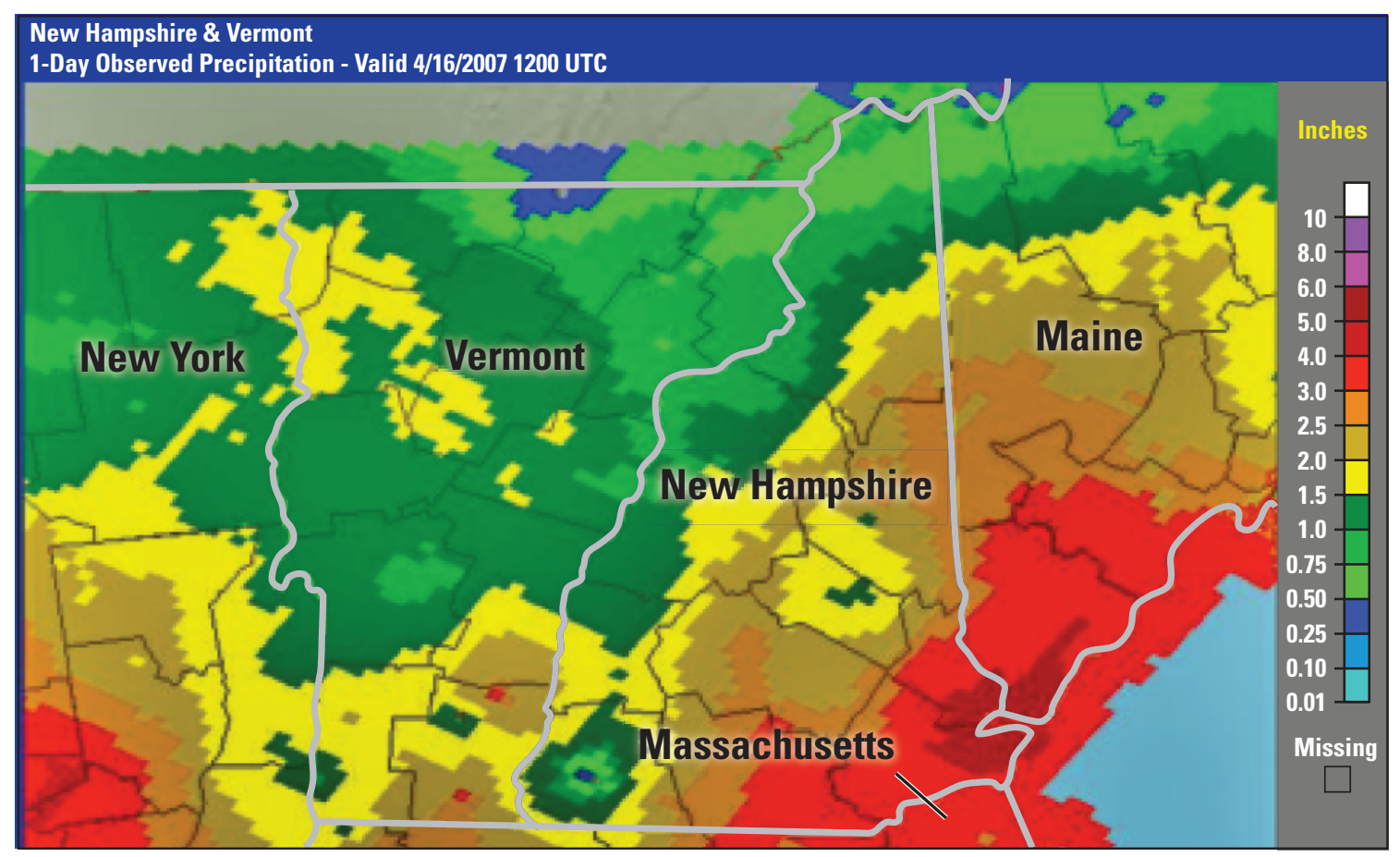

Figure 2A. The 1-day observed precipitation totals ending on April 16, 2007, New Hampshire and Vermont. (From Northeast River Forecast Center, 2007a)

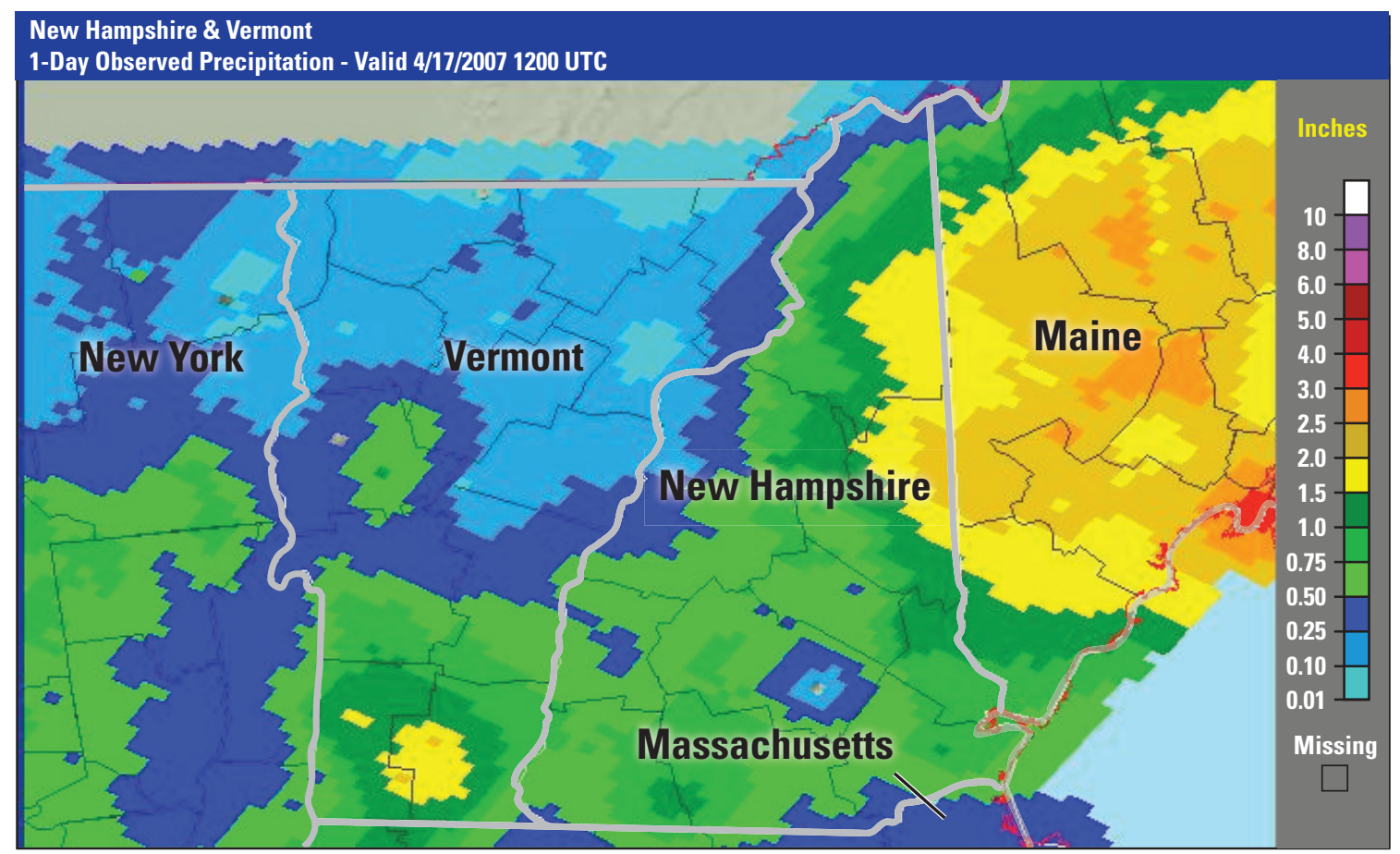

Figure 2B. The 1-day observed precipitation totals ending on April 17, 2007, New Hampshire and Vermont. (From Northeast River Forecast Center, 2007a) 


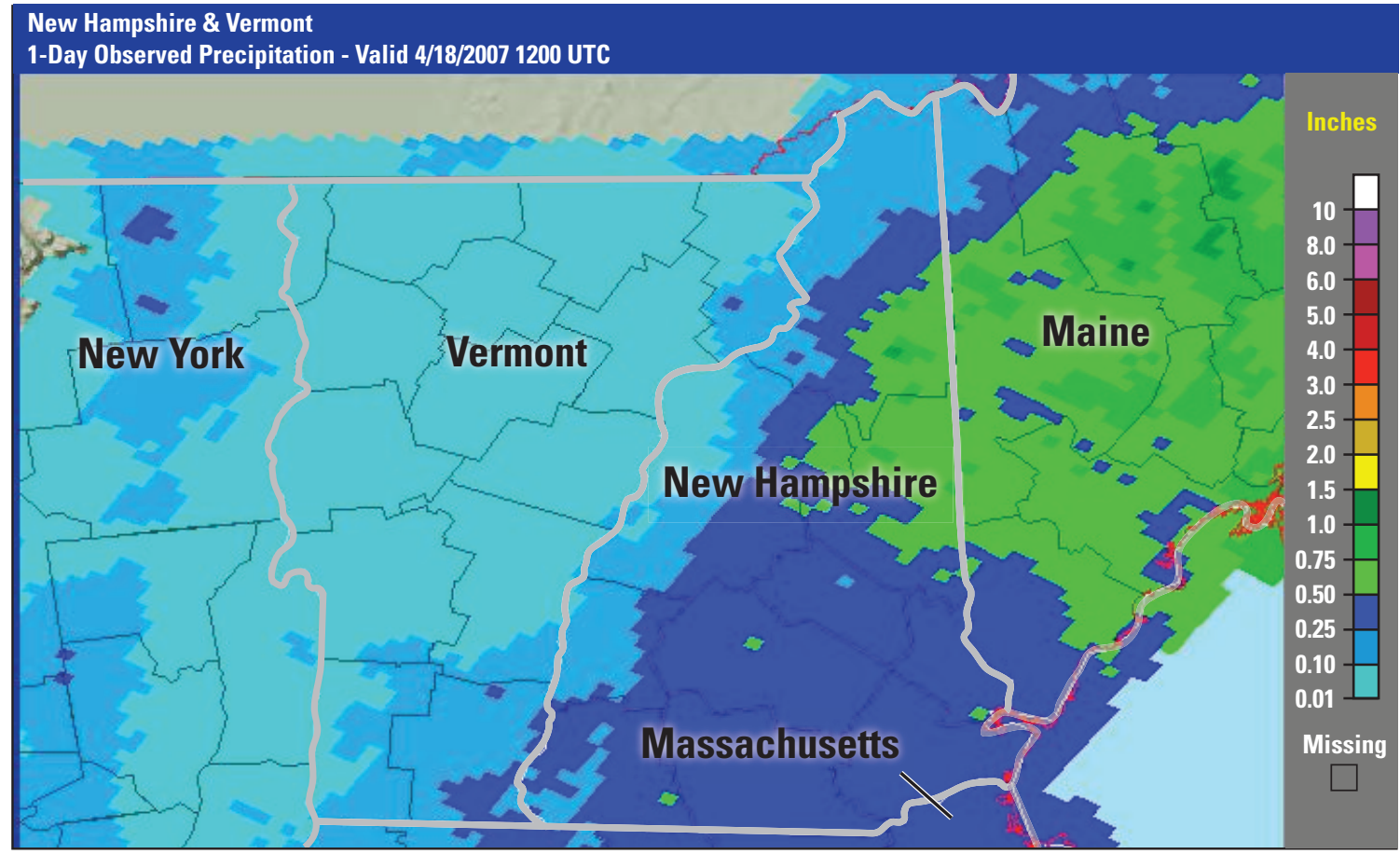

Figure 2C. The 1-day observed precipitation totals ending on April 18, 2007, New Hampshire and Vermont. (From Northeast River Forecast Center, 2007a)

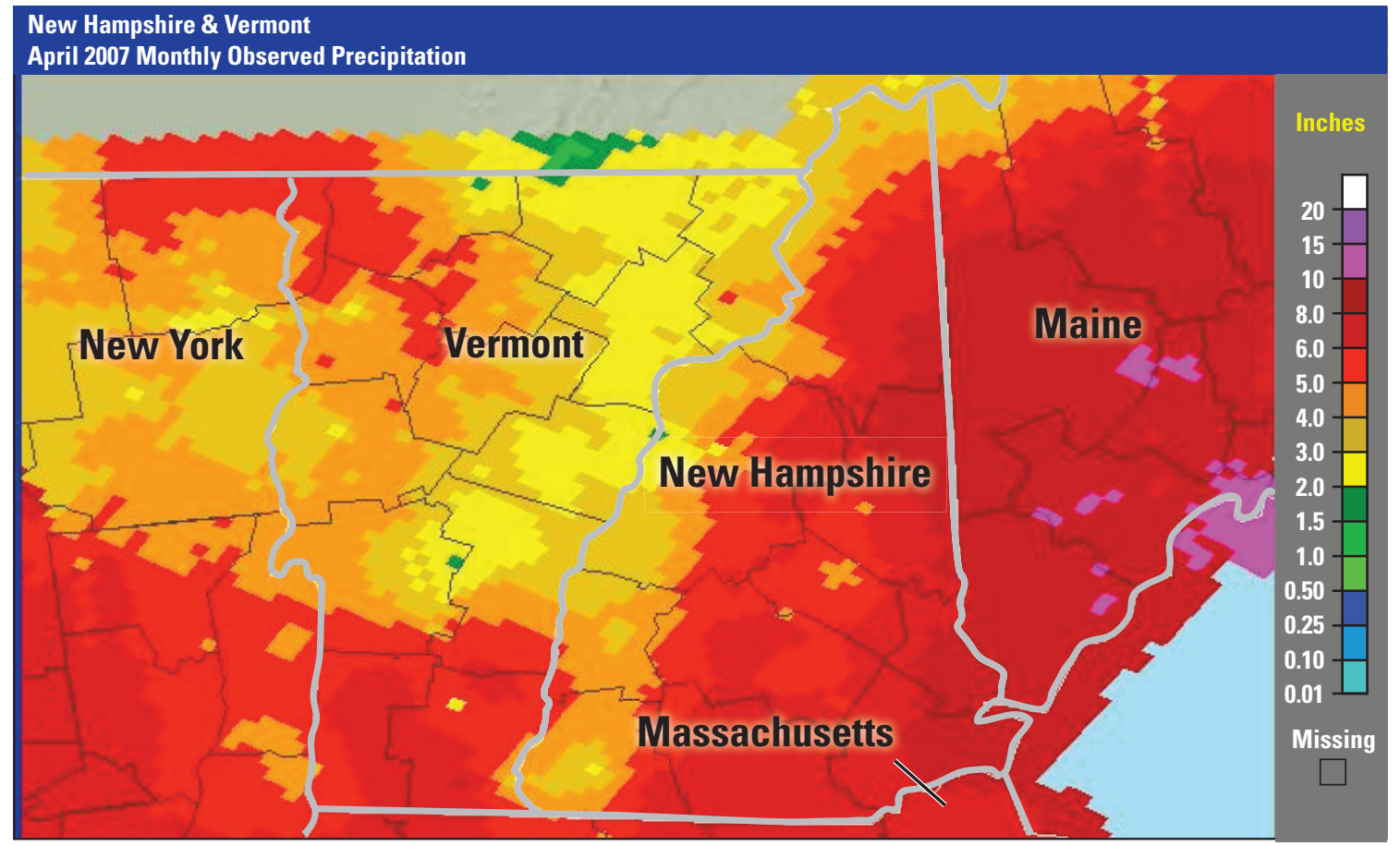

Figure 3. The April 2007 monthly observed precipitation, New Hampshire and Vermont. (From Northeast River Forecast Center, 2007b) 
during May 11-15, 2006, in the south-central part of the state (National Oceanic and Atmospheric Administration, 2006b). The October 20-22, 1996, May 11-15, 2006, and April 15-19, 2007, precipitation events all resulted in streamflow discharges that were the maximum for the periods of record at several streamgages in southern and southeastern New Hampshire.

\section{Peak-Stage Data}

Peak-stage data at active streamgages operated by the USGS were retrieved directly from the stage data recorded at the streamgages, along with the precise date and time of the peak stage. At active streamgages not operated by the USGS, the peak stage with date and time was provided by the station operators. All peak-stage data from active streamgages were rated excellent, which means that measurements are considered to be within $0.05 \mathrm{ft}$ of the actual water surface.

For discontinued streamgages, USGS personnel identified and flagged the April 2007 high-water marks near the streamgage. The high-water marks typically consisted of debris lines, wash lines, or mud lines left behind by the peak water elevation during the flood. The flagged highwater marks were rated for accuracy. This accuracy rating is subjective and is based on the type of high-water mark and the abundance of other confirming marks in the immediate vicinity (Benson and Dalrymple, 1967). The accuracies of the marks are defined as follows. A high-water mark with (1) an excellent rating is thought to be within $0.05 \mathrm{ft}$ of the actual water surface; (2) a good rating, within $0.1 \mathrm{ft}$; (3) a fair rating, within $0.2 \mathrm{ft}$; and (4) a poor rating, greater than $0.2 \mathrm{ft}$ from the true water surface.
The flagged high-water marks at the discontinued streamgages were referenced to the datum of the streamgage by using closed level-loop surveying techniques (elevations were determined at the high-water marks by differential leveling from a known elevation datum). The streamgage datum is the local base elevation that was used in developing the stage-discharge relationship when the streamgage was active. Because the high-water marks were referenced to the streamgage datum, the marks represented the peak stages of the flooding at the discontinued streamgage. The date of the peak stages at discontinued streamgages was estimated from peak-stage hydrographs for active streamgages in the same or adjacent watersheds.

At active streamgages as well as at discontinued streamgages where high-water marks had been flagged, the peak stage was referenced to the National Geodetic Vertical Datum of 1929 (NGVD 29) and the NAVD 88 by using closed level-loop surveying techniques from either a known reference datum or from a reference datum established using Leica System 1200 Global Positioning System (GPS) with 3-mm (0.01-ft) horizontal accuracy and $10-\mathrm{mm}(0.03-\mathrm{ft})$ vertical accuracy in static mode (Leica Geosystems, 2008). Referencing the peak stage to NGVD 29 and NAVD 88 allows the high-water mark to be compared to the existing FEMA FloodInsurance Study data for the streamgage location.

The peak-stage data for all sites included in this investigation are shown in table 2 . The location of each streamgage is shown, by county, in figures $4 \mathrm{~A}-\mathrm{G}$. Although a disaster declaration was not made in Carroll County (fig. 4G), flows at four streamgages in that county were investigated because of their close proximity to Belknap and Grafton Counties, which were declared disaster areas (table 1, in back of report). 


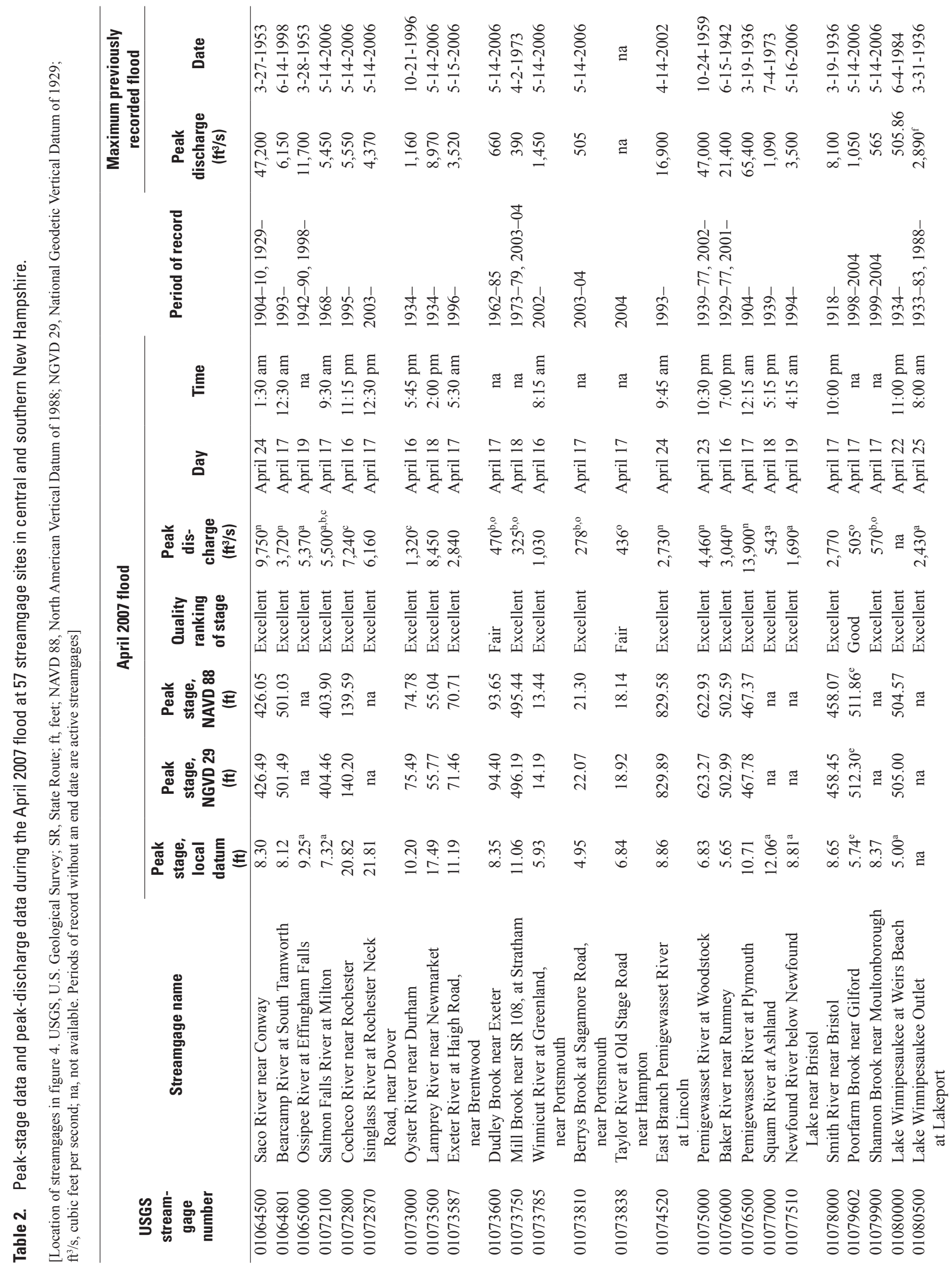




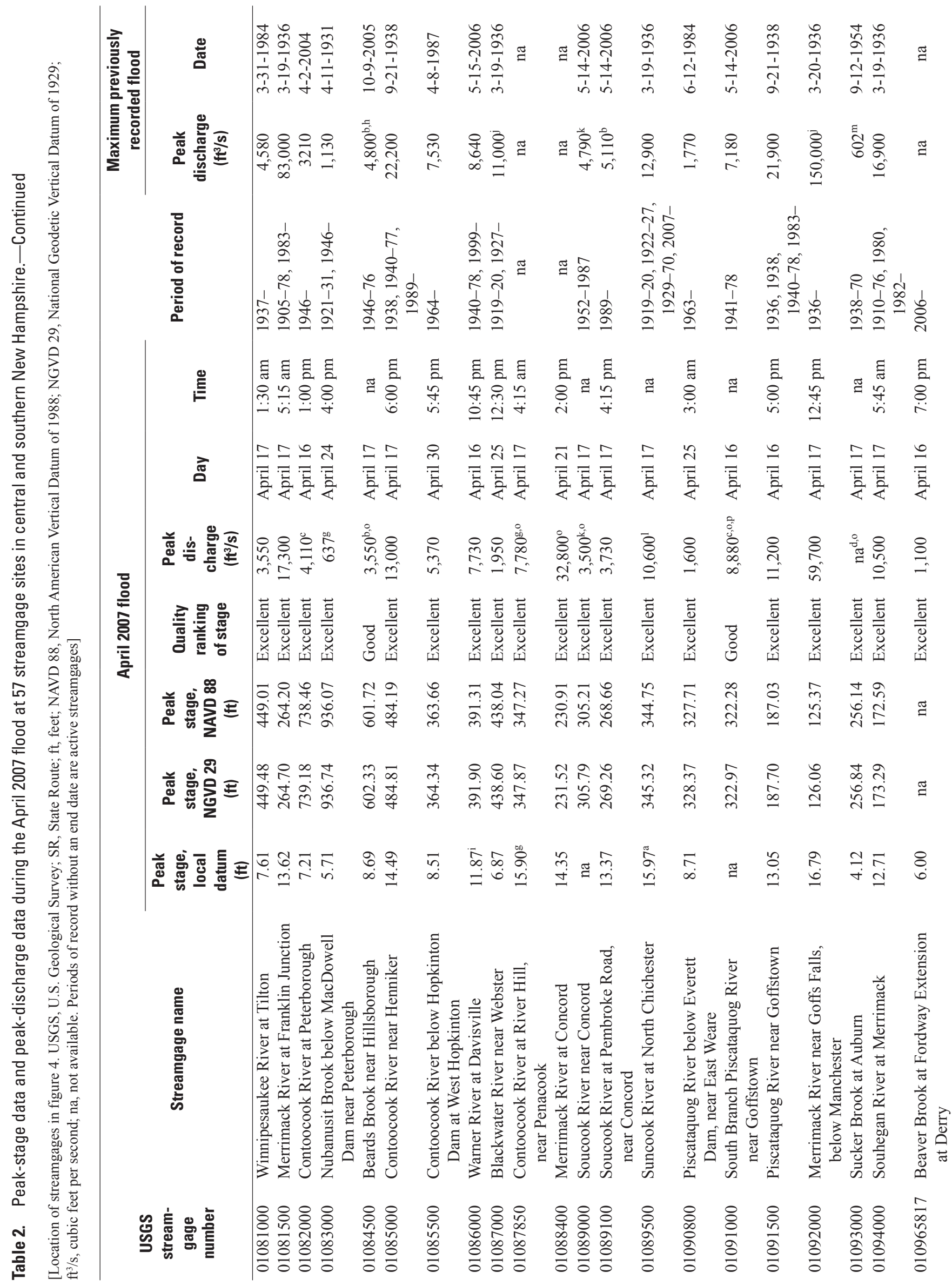




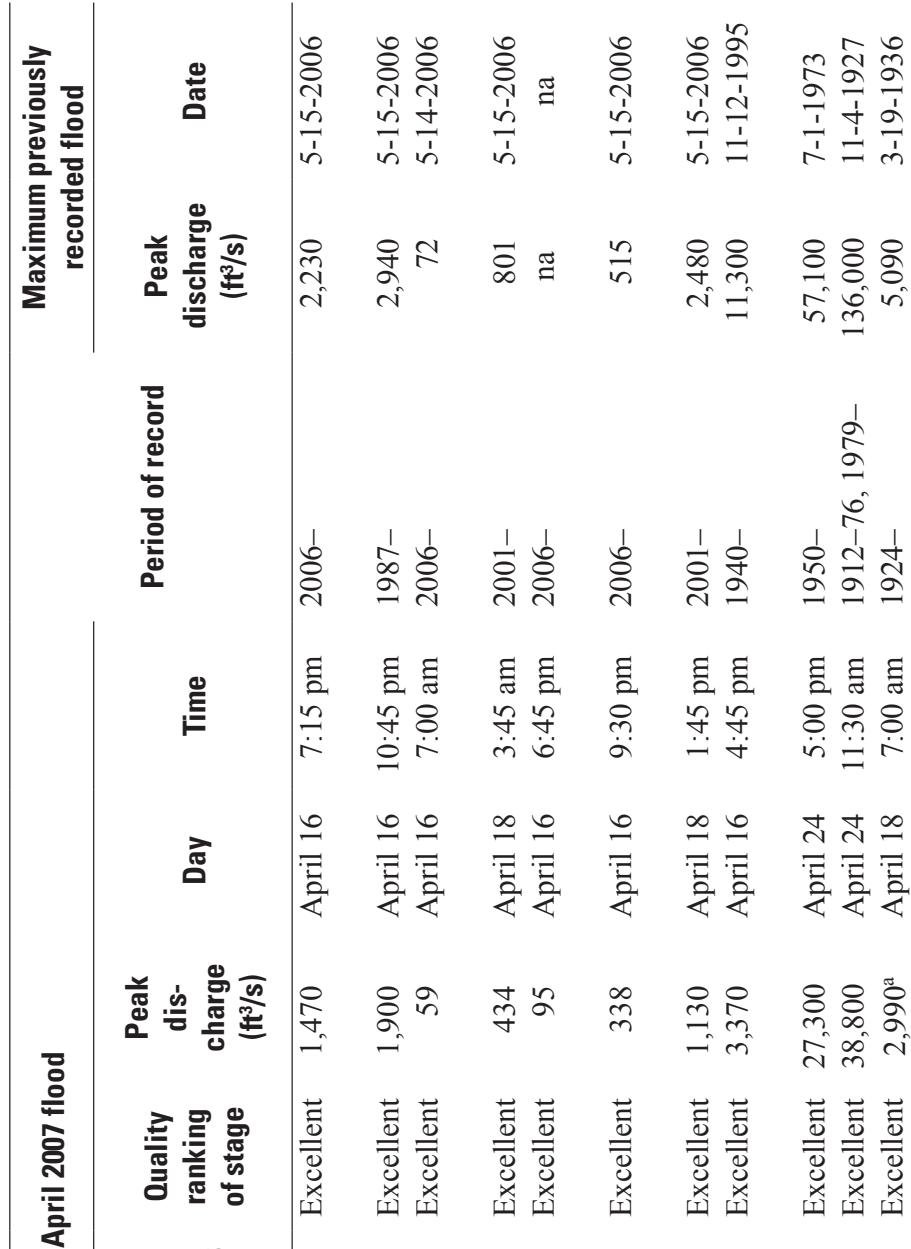

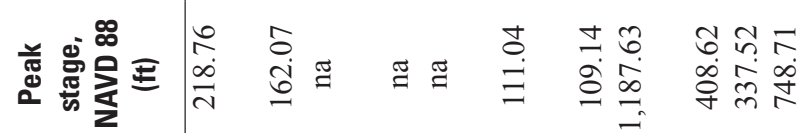

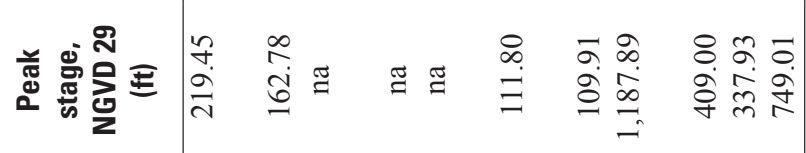

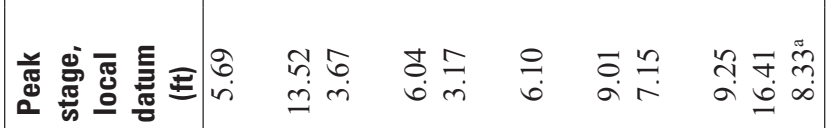




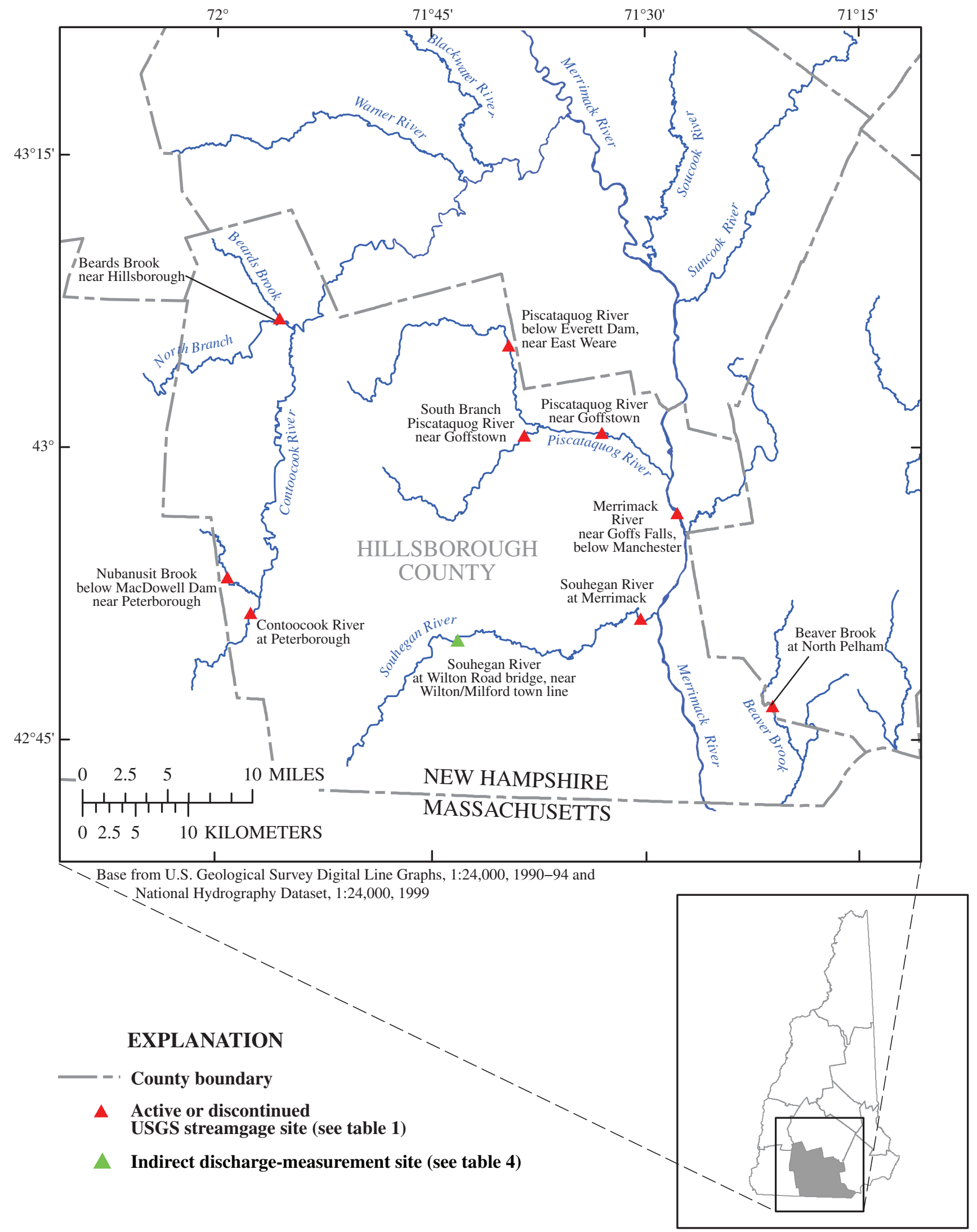

Figure 4A. Location of U.S. Geological Survey (USGS) streamgage sites and indirect discharge-measurement sites having peak stage and discharge data for the April 2007 flood in Hillsborough County, New Hampshire. 


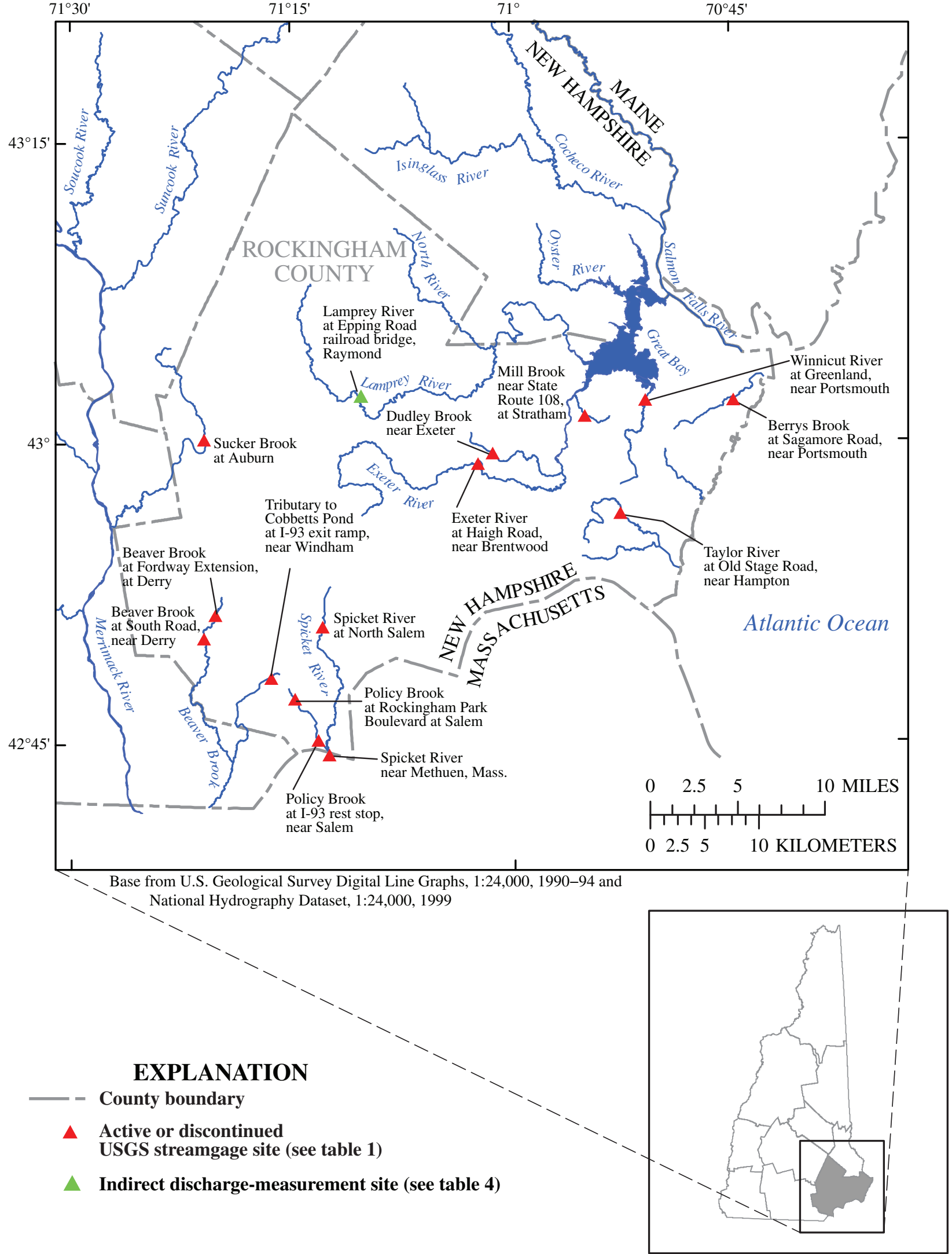

Figure 4B. Location of U.S. Geological Survey (USGS) streamgage sites and indirect discharge-measurement sites having peak stage and discharge data for the April 2007 flood in Rockingham County, New Hampshire. 


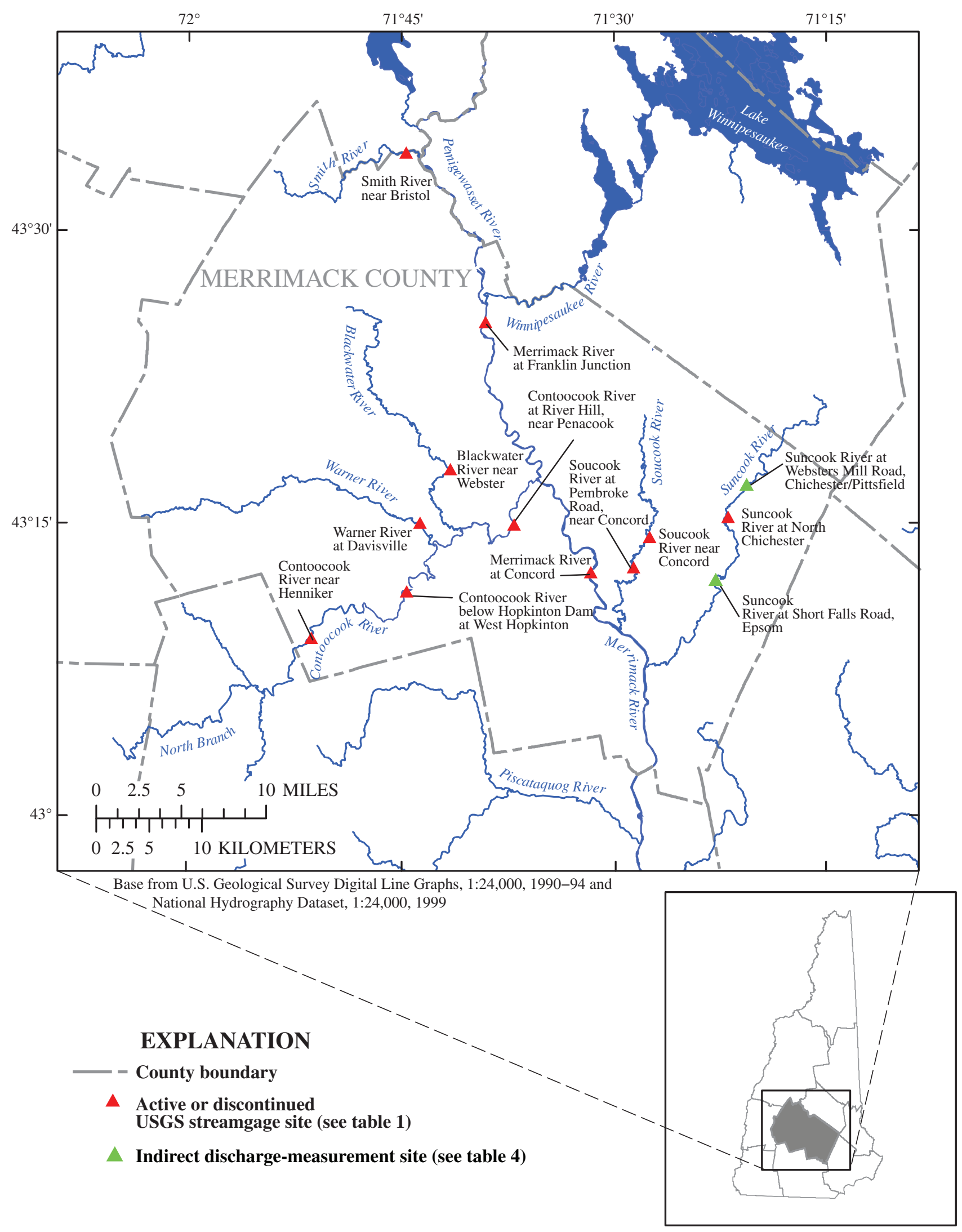

Figure 4C. Location of U.S. Geological Survey (USGS) streamgage sites and indirect discharge-measurement sites having peak stage and discharge data for the April 2007 flood in Merrimack County, New Hampshire. 


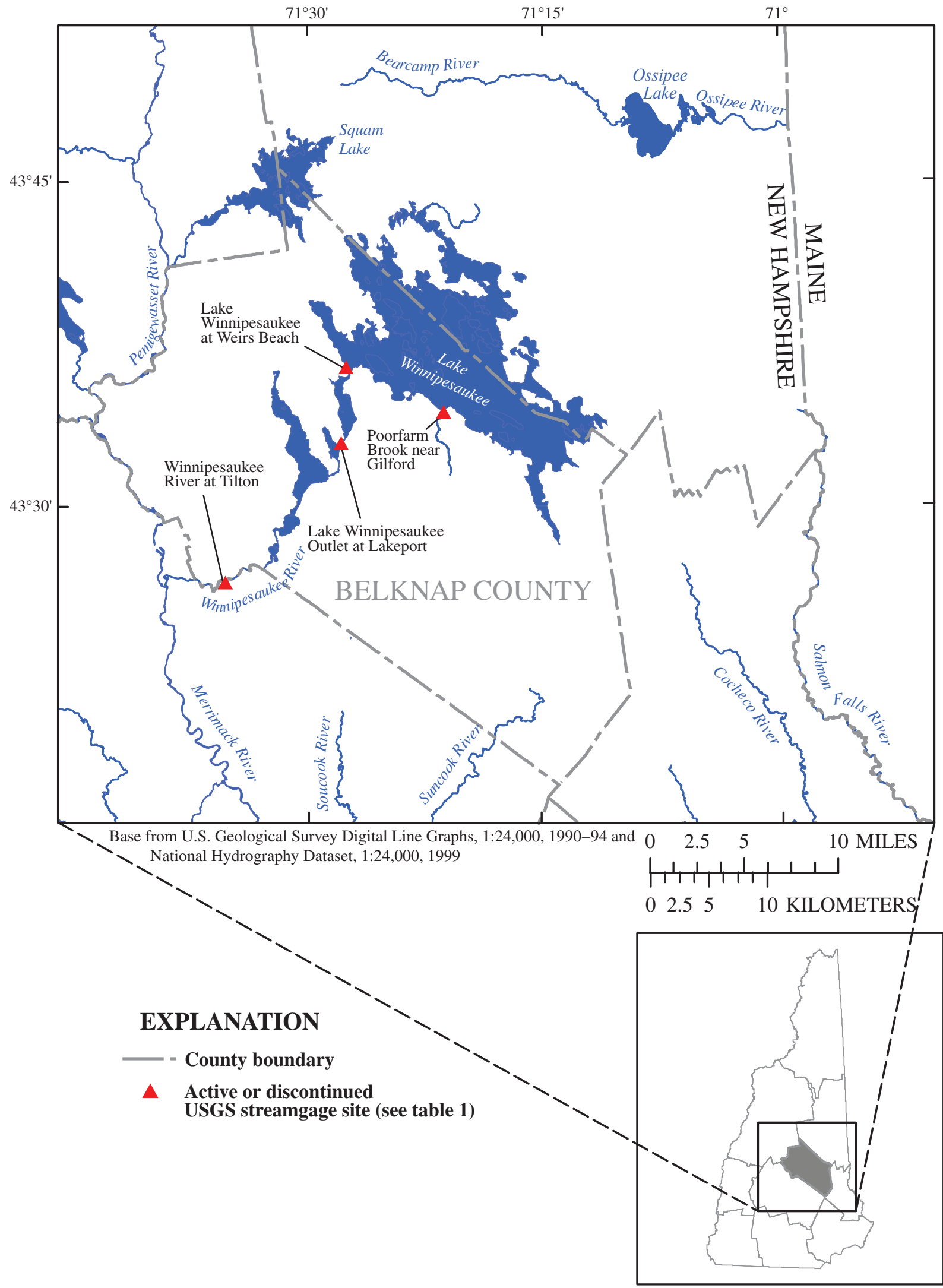

Figure 4D. Location of U.S. Geological Survey (USGS) streamgage sites having peak stage and discharge data for the April 2007 flood in Belknap County, New Hampshire. 


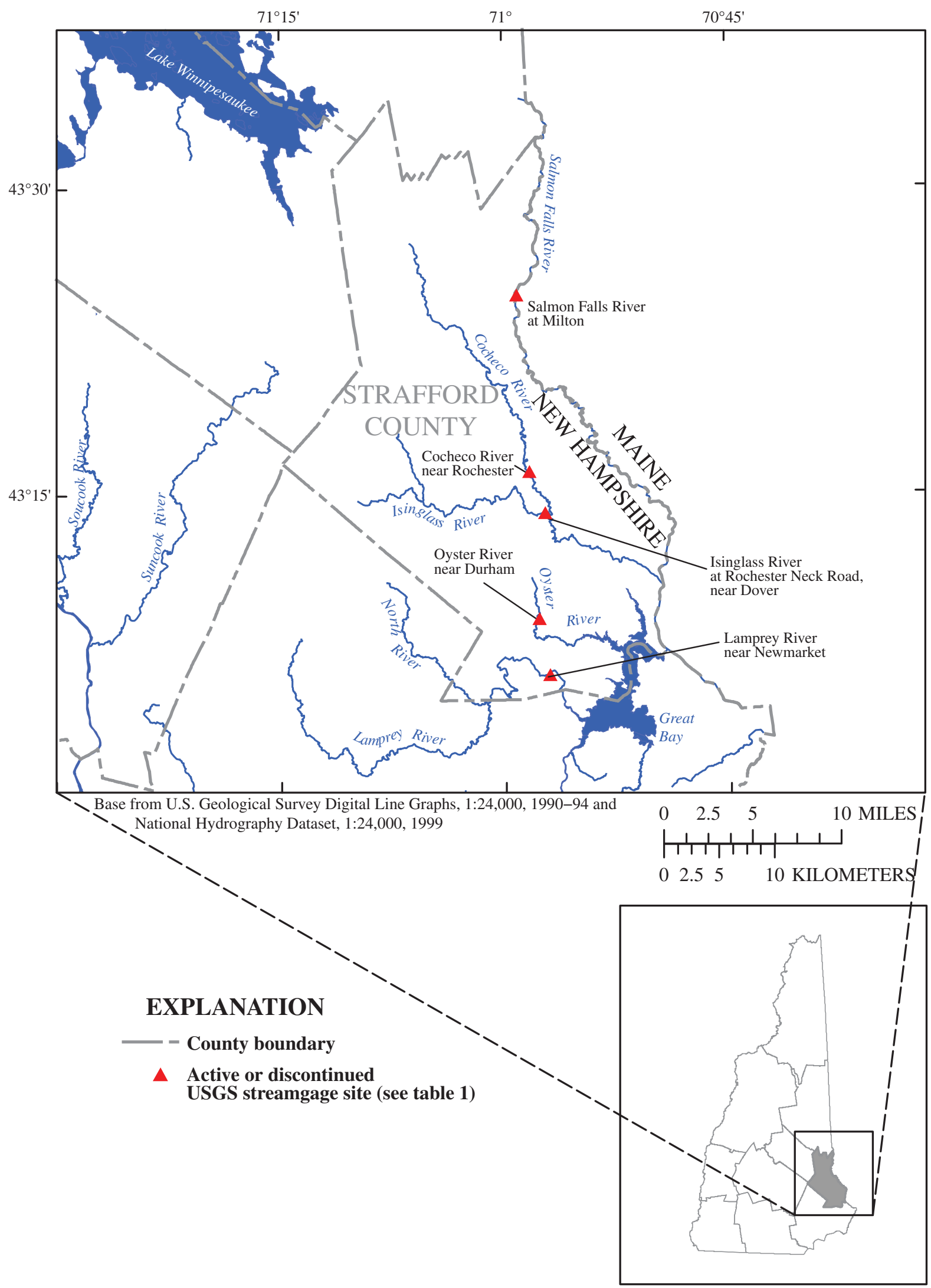

Figure 4E. Location of U.S. Geological Survey (USGS) streamgage sites having peak stage and discharge data for the April 2007 flood in Strafford County, New Hampshire. 

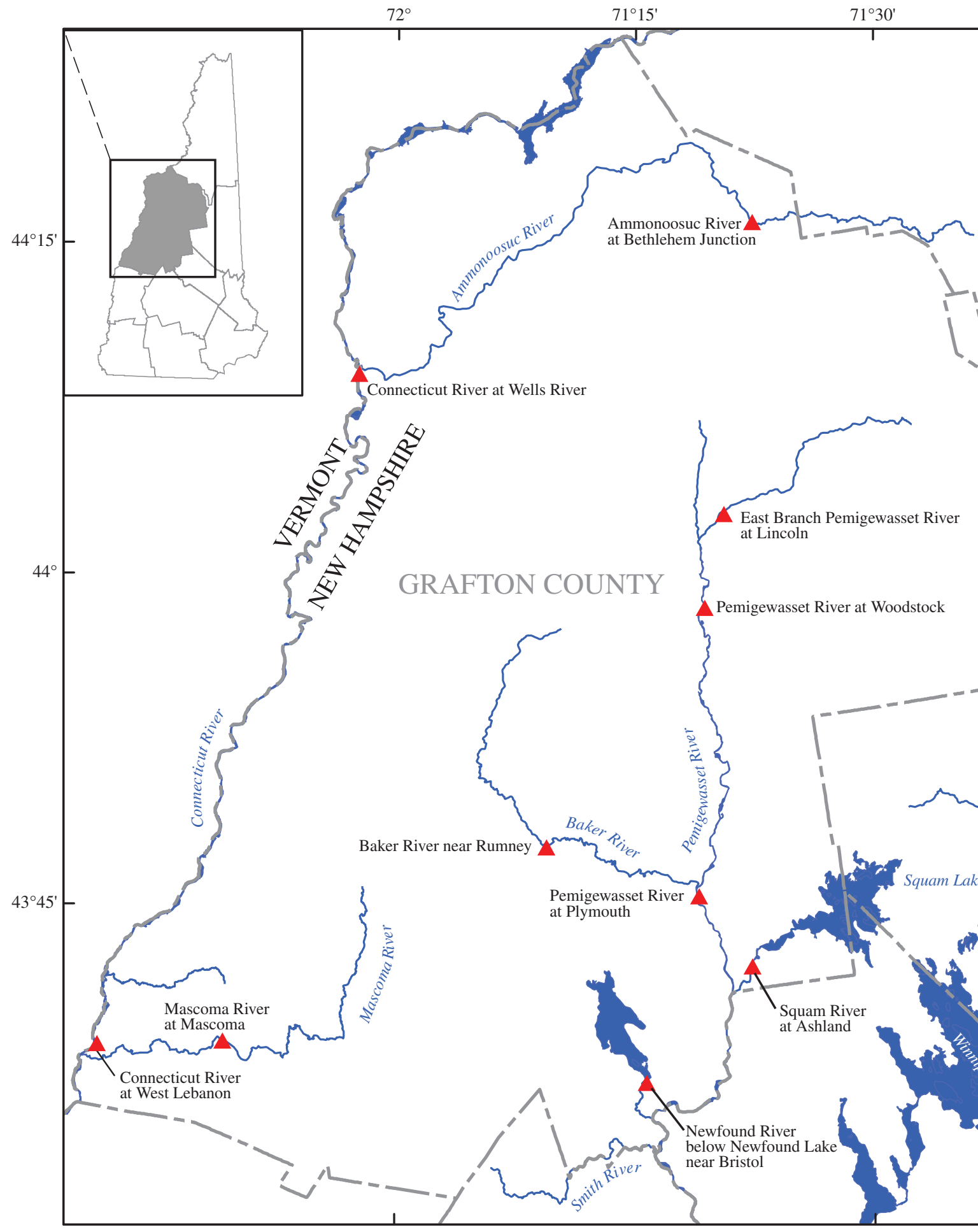

$71^{\circ} 15^{2}$ Ammonoosuc River
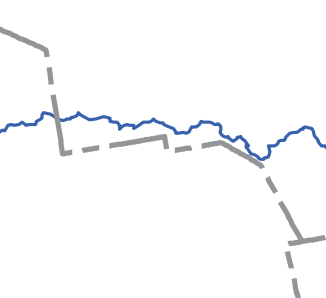


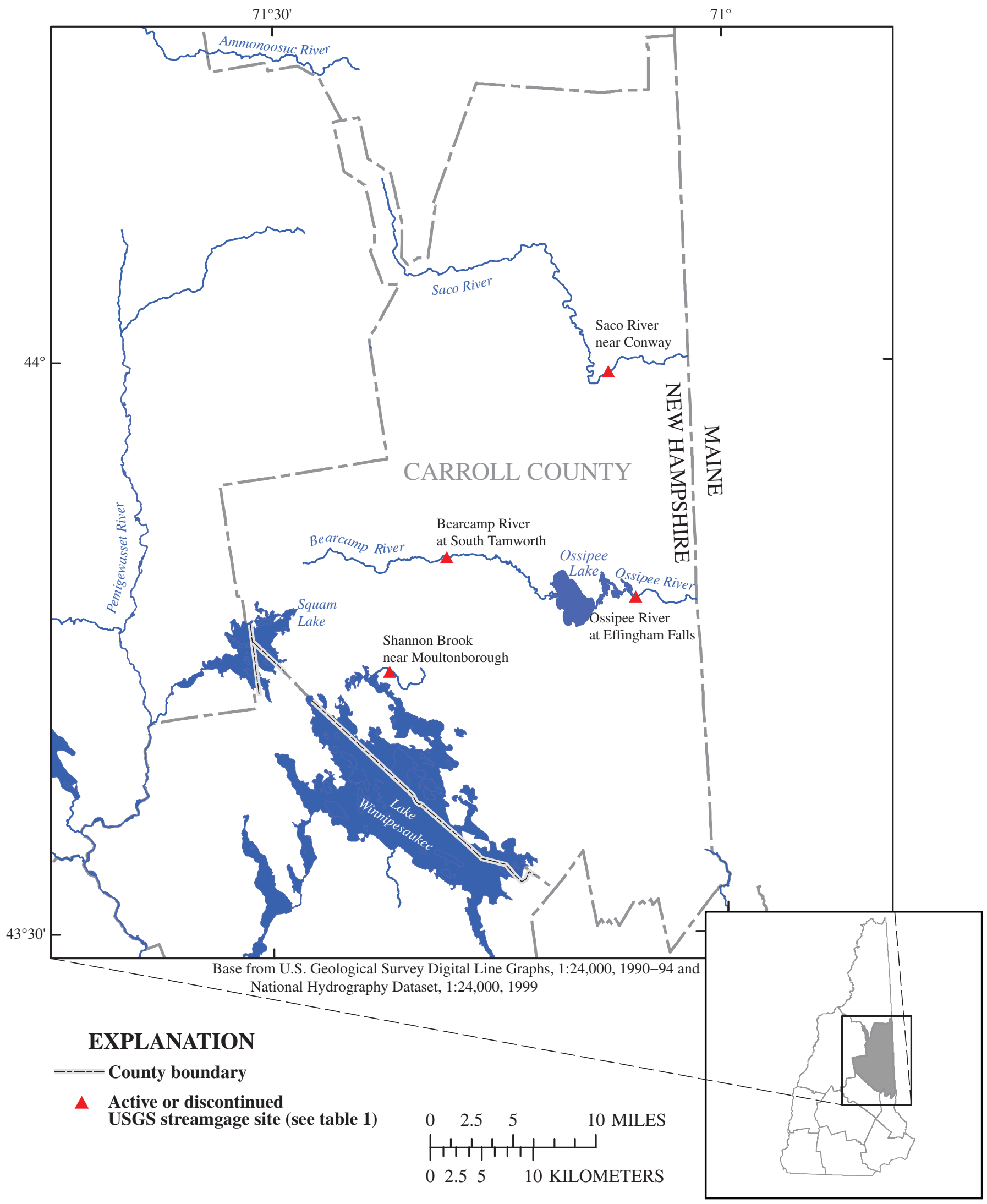

Figure 4G. Location of U.S. Geological Survey (USGS) streamgage sites having peak stage and discharge data for the April $2007 \mathrm{flood}$ in Carroll County, New Hampshire. 


\section{Peak-Discharge Data}

Peak discharges for most streamgages were determined by applying the peak stage to the most current stagedischarge relation developed for that streamgage (table 2).

At discontinued streamgages, there is the possibility that the stage-discharge relation has changed during the years that the site has been inactive. Each of the discontinued streamgages, however, is at a site having a stable channel or control, and the most recent stage-discharge relationship available for the site provides reasonable results.

There were four exceptions to using the stagedischarge relation for determining the peak-discharge of the April 2007 flood:

1. At six streamgages $(01072100,01073600,01073750$, 01073810, 01079900, and 01084500; table 2, footnote b), the current stage-discharge relation was undeveloped for the unusually large peak stage. In such cases, the stagedischarge relation was graphically extended to the peak stage by using the trend of the upper end of the stagedischarge relation. The error introduced to the peak-discharge value is unknown when the stage-discharge relation is extended without manually measured discharges.

2. At discontinued streamgage 01093000, Sucker Brook at Auburn (fig. 4B; table 2, footnote d), Rockingham County, backwater resulting from hydraulic conditions in the channel downstream from the streamgage prevented the use of the stage-discharge relation to determine the peak discharge from the peak stage. The peak discharge at this streamgage is therefore unknown.

3. At discontinued streamgage 01091000 (drainage area of $104 \mathrm{mi}^{2}$ ), South Branch Piscataquog River near Goffstown, N.H. (fig. 4A; table 2, footnote p), Hillsborough County, the USGS streamgage house was removed and datum reference marks were destroyed during the construction of a new bridge in 2003. Because the reference marks were destroyed, it was not possible to tie the surveyed high-water marks at this site to the streamgage datum. Without this information, the stagedischarge relation for the streamgage could not be used. Although enough high-water marks were available upstream and downstream from the bridge to allow a discharge estimate to be made at the bridge by using indirect techniques (Matthai, 1967), the area upstream from the bridge experienced backwater effects during the April 2007 flood. This invalidated the use of indirect techniques to determine the April 2007 flood discharge at this location.

High-water-mark elevation data were collected upstream and downstream from discontinued streamgage 01091000 at the Route 13 (Mount Vernon Road) bridge (drainage area of $54 \mathrm{mi}^{2}$ ) over the South Branch Piscataquog River in New Boston. These data were collected to determine the peak flow for the April 2007 flood at the Route 13 bridge as well as at discontinued streamgage 01091000 by using the ratio of the drainage areas between the Route 13 bridge and the discontinued streamgage. Although the bridge provides sufficient river constriction to allow a discharge estimate to be made by using indirect methods (Matthai, 1967), subsequent information provided by two residents living near the Route 13 bridge indicated that the main channel of the South Branch Piscataquog River overtopped the banks upstream from the Route 13 bridge, and water flowed down a road $500 \mathrm{ft}$ south of the bridge, along the downstream side of Route 13, and back into the South Branch Piscataquog River downstream from the Route 13 bridge. This road overflow invalidated a discharge determination made by indirect methods at the Route 13 bridge in New Boston.

Peak discharge at discontinued streamgage 01091000, South Branch Piscataquog River near Goffstown, N.H., could not be determined by indirect methods due to backwater effects, nor could it be determined at the Route 13 bridge over the South Branch Piscataquog River in New Boston due to flow on the upstream right overbank. It was decided, however, that the April 2007 peak discharge at streamgage 01091000 , could be determined by using the ratio of the drainage area for this streamgage to the area for streamgage 01091500 (drainage area of $202 \mathrm{mi}^{2}$ ), Piscataquog River near Goffstown (fig. 4A), downstream from discontinued streamgage 01091000. The South Branch Piscataquog River flows into the Piscataquog River downstream from streamgage 01090800 (drainage area of $63 \mathrm{mi}^{2}$ ) at Piscataquog River below Everett Dam, near East Weare and upstream from streamgage 01091500 at Piscataquog River near Goffstown. Determination of the April 2007 peak discharge by ratio of drainage areas between the South Branch Piscataquog River near Goffstown and Piscataquog River near Goffstown streamgages was deemed acceptable because there was negligible contribution to flow downstream from the Hopkinton-Everett Lake Dam (as recorded at streamgage 01090800, Piscataquog River below Everett Dam, near East Weare) to the peak flood flow at the Piscataquog River near Goffstown, N.H. streamgage. The 202-mi drainage area of the Piscataquog River near Goffstown, N.H. streamgage was adjusted to $139 \mathrm{mi}^{2}$ to reflect the negligible contribution of 20-50 $\mathrm{ft}^{3} / \mathrm{s}$ (U.S. Army Corps of Engineers, 2007) for April 16-17, 2007, below the Hopkinton-Everett Lake Dam in Contoocook as measured at the Piscataquog River below Everett Dam, near East Weare. The peak discharge at streamgage 01091000, South Branch Piscataquog River near Goffstown, was $11,200 \mathrm{ft}^{3} / \mathrm{s}$ on April 16 at $5 \mathrm{pm}$. The flood-peak discharge for the April 2007 flood at the discontinued South Branch Piscataquog River near Goffstown streamgage was estimated to be $8,880 \mathrm{ft}^{3} / \mathrm{s}$ by adjusting the peak 
discharge (using equation 1-explained in the section "Determination of the April 2007 Flood Discharge by Indirect Methods at Ungaged Sites") determined for the downstream Piscataquog River near Goffstown streamgage by the ratio of the drainage areas for streamgages at South Branch Piscataquog River near Goffstown and Piscataquog River near Goffstown.

4. USGS streamgage 01089500 (drainage area of $155 \mathrm{mi}^{2}$ ), Suncook River at Depot Road in North Chichester (fig. 4C; table 2, footnote 1), Merrimack County, was active during 1919 to 1920,1922 to 1927 , and 1929 to 1970 . In November of 2007, it was again activated. After the April 16-18, 2007, flood, high-water mark information was collected at the former streamgage site. By using the streamgage rating (stage/discharge relation) established for the period of record prior to 1970 , a peak discharge of $15,000 \mathrm{ft}^{3} / \mathrm{s}$ was determined for the former location of the Suncook River at Depot Road in North Chichester streamgage for the April 16-18, 2007, flood. Subsequently, indirect discharge determinations were made at locations upstream and downstream from the discontinued streamgage. These locations are at the Websters Mill Road bridge in Chichester/Pittsfield and Short Falls Road bridge in Epsom, with drainage areas of 137 and $210 \mathrm{mi}^{2}$, respectively. The high-water marks upstream and downstream from each bridge, the bridgeopening geometry, and channel and floodplain cross sections upstream and downstream from the bridge were surveyed and the values were input to the USACE Hydrologic Engineering Center River Analysis System (HEC-RAS) program (2005). Discharges were selected iteratively and input to the HEC-RAS program so that the resulting water-surface-elevation output from the program matched the high-water marks surveyed upstream from the bridge. A flood-peak discharge of 10,600 ft $\mathrm{ft}^{3} / \mathrm{s}$ was determined for the former Suncook River at Depot Road in North Chichester streamgage site on the basis of the discharge/drainage-area relation between the two indirectly determined (Matthai, 1967; U.S. Army Corps of Engineers, 2005) April 2007 flood-peak discharges at the Short Falls and Websters Mill Road bridges on the Suncook River. The upper end of the rating (stage/ discharge relation) at the former streamgage has shifted since it was determined from the March 19, 1936, flood data, when a discharge of $12,900 \mathrm{ft}^{3} / \mathrm{s}$ at a gage height of $15.27 \mathrm{ft}$ was ascertained by slope-area and contractedopening methods. The shift in the upper end of the rating likely is due to a greater amount of vegetation on the right overbank in 2007 than in 1936 (as seen in USGS photographs on file at the New Hampshire-Vermont Water Science Center) and the construction of a weir control along with the removal of a channel island below the streamgage in the summer of 1937. For this reason, the discharge of $10,600 \mathrm{ft}^{3} / \mathrm{s}$ was determined to be the peak discharge for the April 16-18, 2007, flood at the former streamgage.

The peak-discharge data for all of the sites included in this investigation are shown in table 2. At five long-term (more than 10 years of record) streamgages, the peak discharge from the April 2007 flood was the maximum discharge for the period of record. The discharges for these five streamgages are listed in table 2 in footnote c. Four of these streamgages have very long periods of record: streamgage 01091000, South Branch Piscataquog River near Goffstown, 1941-78; streamgage 01082000, Contoocook River at Peterborough, 1946-present (2007); streamgage 01073000, Oyster River near Durham, 1934-present (2007); and streamgage 01072100, Salmon Falls River at Milton, 1968-present (2007).

\section{Flow-Frequency Analyses of the April 2007 Flooding}

Flow-frequency curves were determined for all 57 streamgages included in this investigation. For 39 of the 57 streamgages, the guidelines in Bulletin 17B (U.S. Interagency Advisory Committee on Water Data, 1982) were used to determine flow-frequency curves. Bulletin 17B recommends the use of a log-Pearson Type III distribution for estimating flow frequency and provides procedures for weighting station skews, determining historical peaks, and detecting and treating outliers and trends. Bulletin 17B also recommends at least 10 years of streamgage record for a flow-frequency analysis. Software developed by the USGS to analyze peakflow frequency (PeakFQ) was used for these computations (U.S. Geological Survey, 2007a). The peak-flow data used as input to the PeakFQ program were retrieved from the National Water Information System (NWIS) (U.S. Geological Survey, 2007b). When the flow-frequency curves were computed, if peak discharges at a streamgage were affected by regulation, the station skew-without weighting from the generalized skew as described in Bulletin 17B - was used for computing the frequency curve. If the April 2007 peak discharge was the annual peak for the 2007 water year, it was added to the peakflow data prior to computing the frequency curves.

For 11 of the 57 streamgages, flood-control structures operated by the USACE are in the basin. Flow-frequency data for 3 of these 11 streamgages were obtained from frequency curves developed by the USACE and published in FEMA Flood-Insurance Studies (table 3, footnote a). At 8 of the 11 streamgages, the flow-frequency curve published in the FEMA Flood-Insurance Study was not developed by the USACE and was recomputed for this study by following the Bulletin 17B guidelines and incorporating peak-flow data collected since the flood-control structures were built.

At 10 of the 57 streamgages in this investigation, a record length of 10 or fewer years was considered insufficient for a 


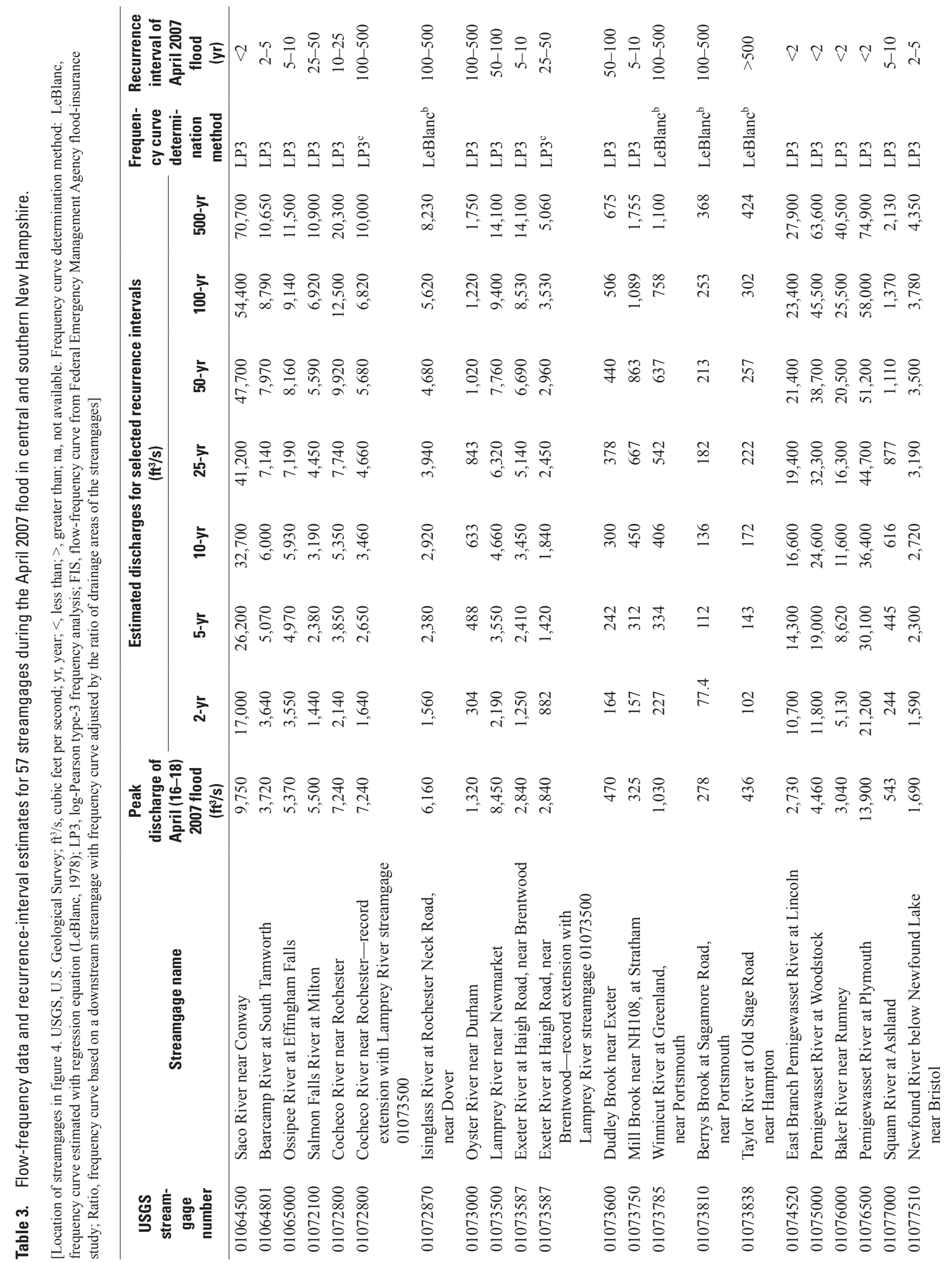




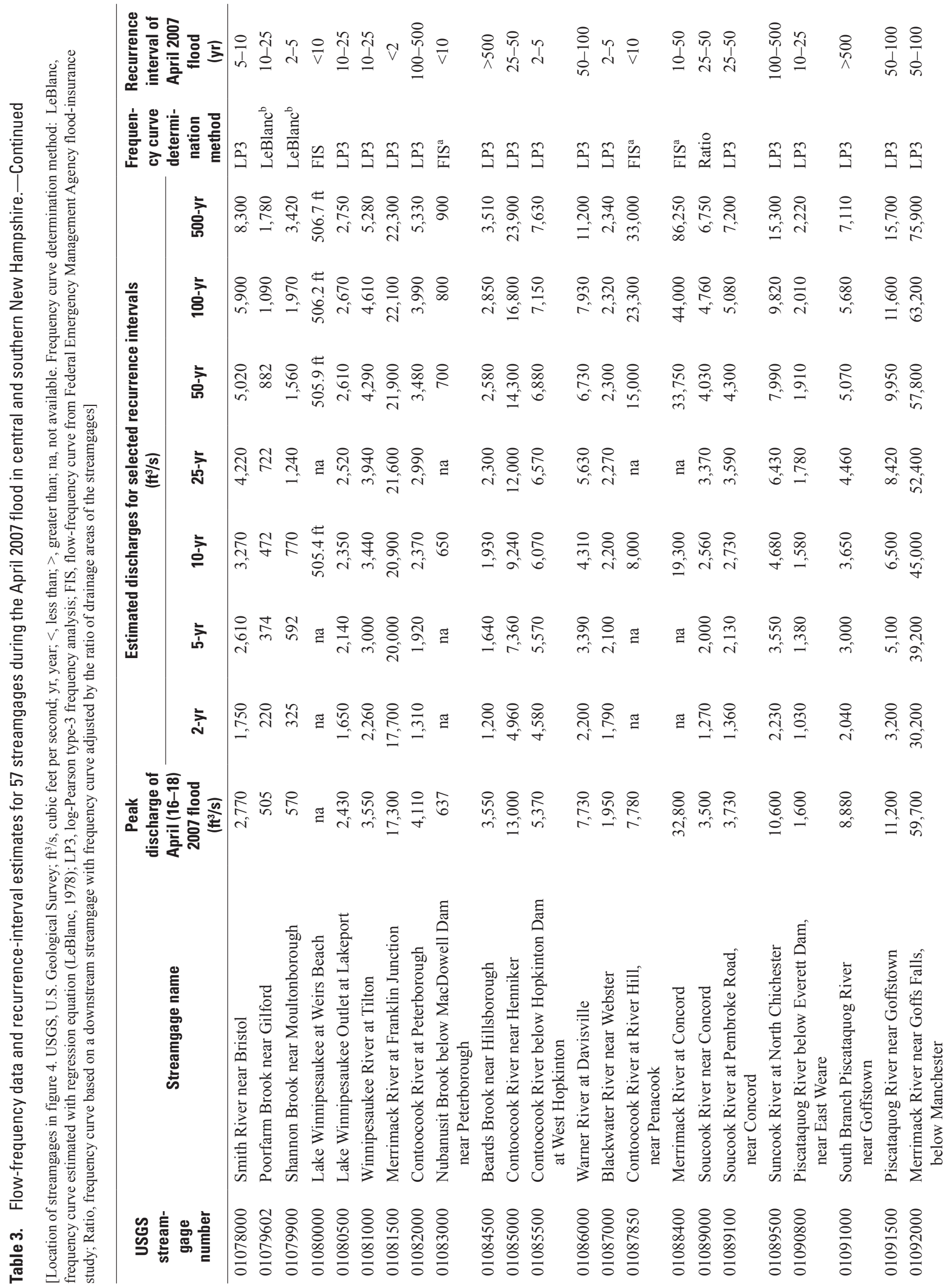




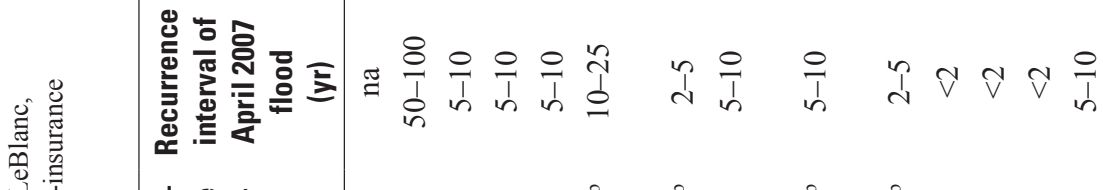

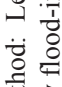

릴 .

疍

馬

可额

施言哭

$\wedge$ 古

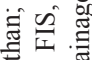

क

v 㲾.

ब

5.

远语

通

政

远

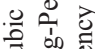

जि बं

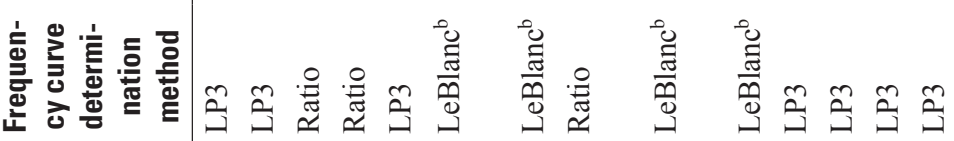

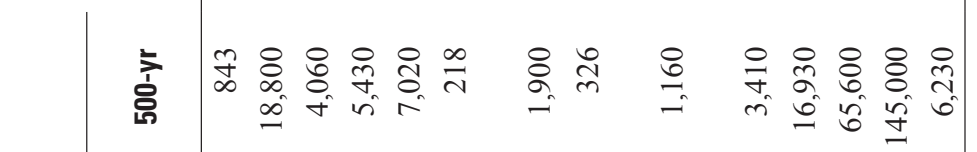

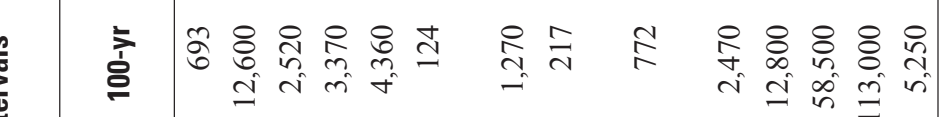

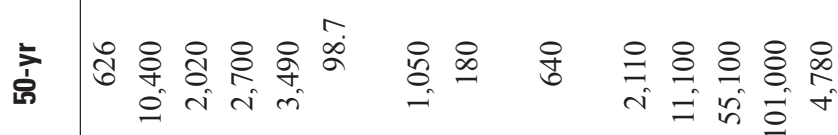

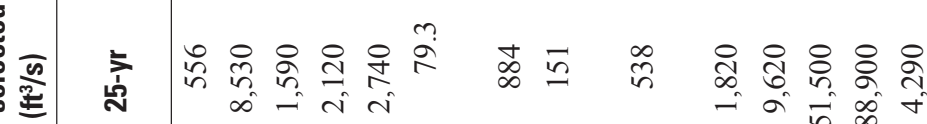

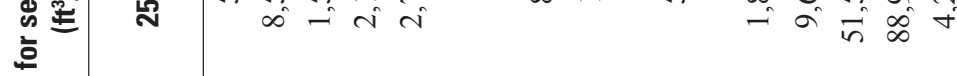

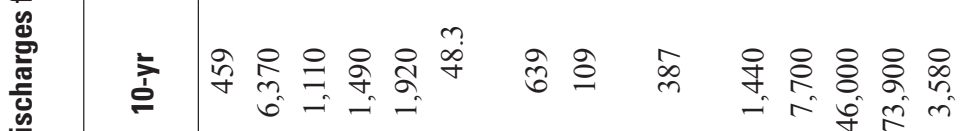

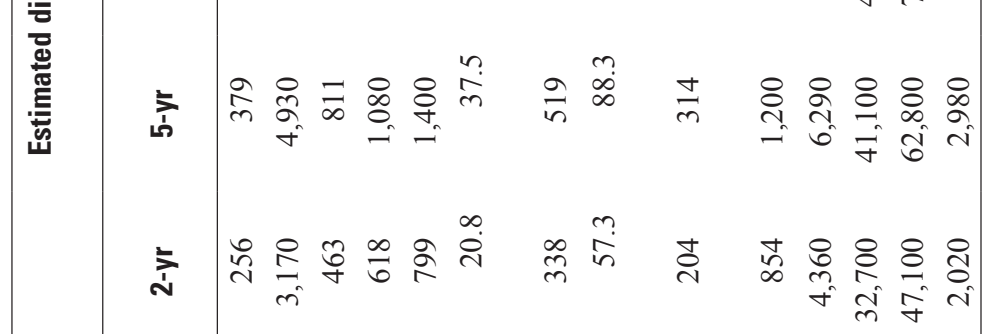

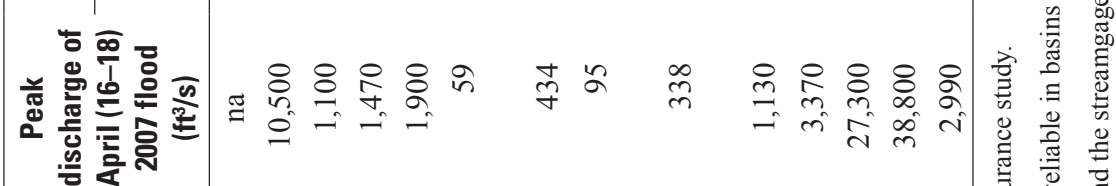
:

这荌

要余品

बल

(5) 응

过

$\dot{\varphi} \dot{0}$

यิ

约

芯新茄苞

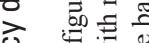

$\Xi 3$

可 क

政

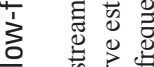

के

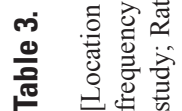

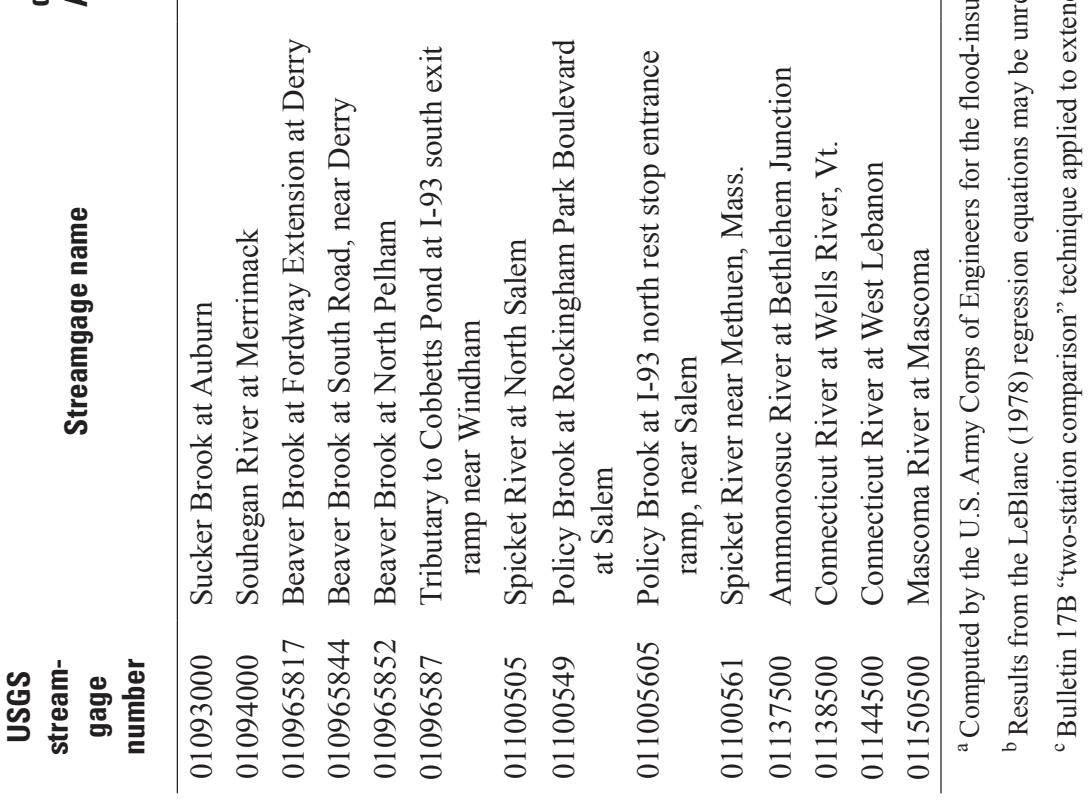




\section{Flood of April 2007 in New Hampshire}

flow-frequency analysis. At these sites, the flow-frequency curves were computed by Olson (2007) by using the regression equations for estimating flow frequency developed by LeBlanc (1978). The resulting frequency curves were not adjusted for urbanization or regulation.

At two streamgages, the flow record was sufficient for flow-frequency analysis; however, both of these sites have a short period of record, and within that short record period, these streamgage sites have experienced severe flooding. The streamgage Cocheco River near Rochester (01072800) (fig. 4E) has 13 years of record, and the streamgage Exeter River at Haigh Road near Brentwood (01073587) (fig. 4B) has 12 years of record. A log-Pearson Type III analysis was performed on the flow record at the streamgages and resulted in a recurrence interval for the April 2007 flood peak of 10 to 25 years for the Cocheco River near the Rochester streamgage and 5-10 years for the Exeter River at Haigh Road near Brentwood streamgage. The two-station-comparison technique in Bulletin 17B was applied to extend the records of these streamgages (S.A. Olson, U.S. Geological Survey, written commun., 2008) by using the long-term streamgage Lamprey River near Newmarket (01073500) (fig. 4E), which has 73 years of record. The records of the streamgages Cocheco River near Rochester and Exeter River at Haigh Road near Brentwood have correlation coefficients with the record of the streamgage at Lamprey River near Newmarket of 0.84 and 0.97 , respectively. The two-station comparison recordextension technique resulted in a recurrence interval for the April 2007 flood peak of 100 to 500 years for the streamgage Cocheco River near Rochester and 25 to 50 years for the streamgage Exeter River at Haigh Road near Brentwood. These data are listed in table 3 and shown in figure 5.
For the streamgage Lake Winnipesaukee at Weirs Beach (01080000), only stage data are available. The frequency data for this site were obtained from the Flood-Insurance Study for the city of Laconia (Federal Emergency Management Agency, 1980a).

Results of the flow-frequency analyses are shown in table 3. The recurrence interval of the April 2007 peak flow at each streamgage was determined by using the results of frequency analysis. Peak discharge equaled or exceeded a 50 -year flood at 16 streamgages. Peak discharge equaled or exceeded a 100-year flood at the 10 streamgages listed below:

1. Cocheco River near Rochester (01072800 — with streamgage-record extension);

2. Isinglass River at Rochester Neck Road, near Dover (01072870);

3. Oyster River near Durham (01073000);

4. Winnicut River at Greenland, near Portsmouth (01073785);

5. Berrys Brook at Sagamore Road, near Portsmouth (01073810);

6. Taylor River at Old Stage Road, near Hampton (01073838);

7. Contoocook River at Peterborough (01082000);

8. Beards Brook near Hillsborough (01084500);

9. Suncook River at North Chichester (01089500); and

10. South Branch Piscataquog River near Goffstown (01091000). 


\section{EXPLANATION}

\section{Lake}

\section{River}

\section{County boundary}

Recurrence interval of peak discharge at streamgages, April 2007 (see table 3).

$\triangle$ Less than 10-year flood

$\triangle$ 10- to less than 50-year flood

$\triangle 50$ - to less than 100-year flood

Equal to or greater than 100-year flood

- Recurrence interval unknown

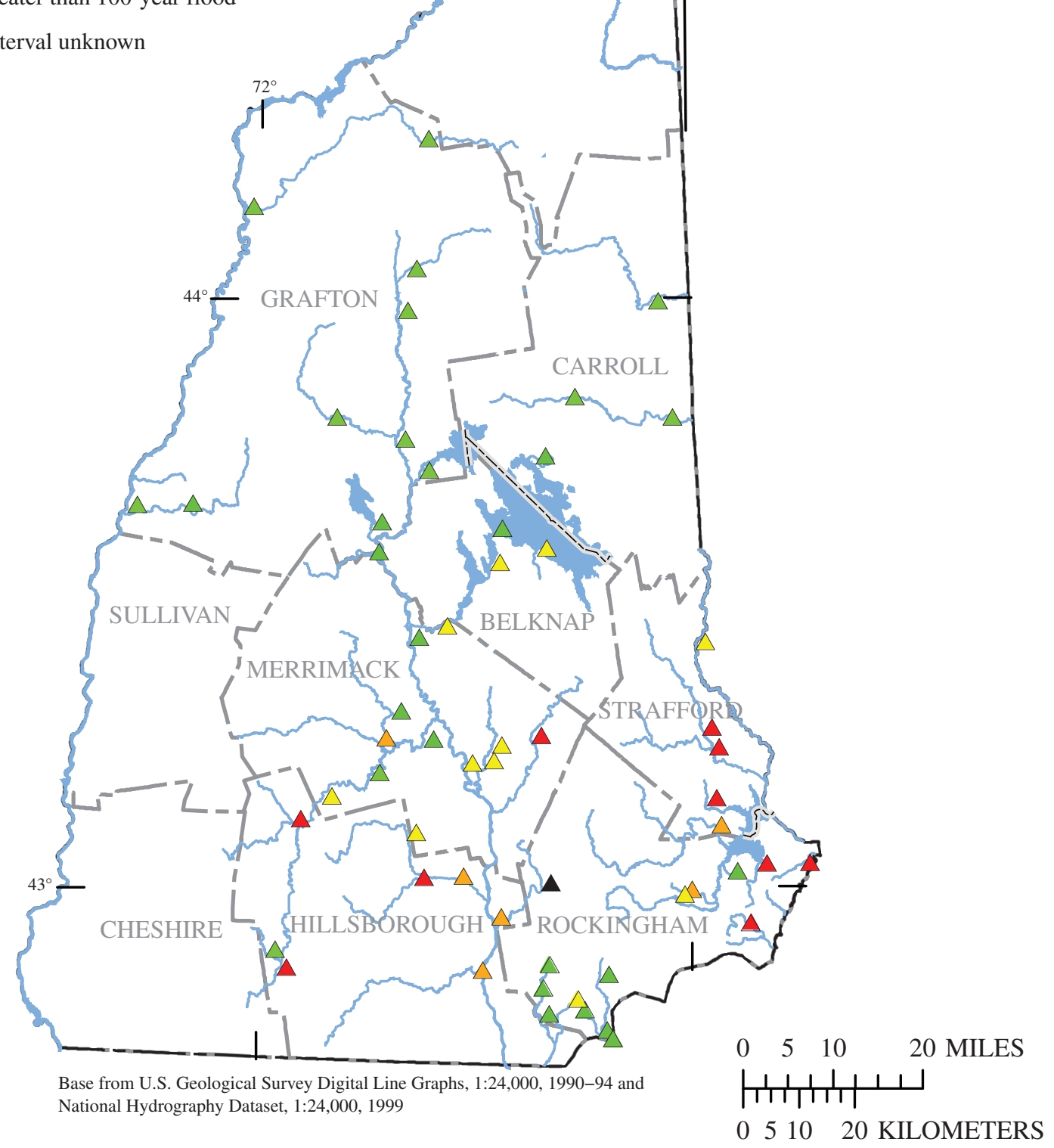

Figure 5. Recurrence intervals for the April 2007 flood at streamgages in Hillsborough, Rockingham, Merrimack, Belknap, Strafford, Grafton, and Carroll Counties in New Hampshire. 


\section{Determination of the April 2007 Flood Discharge by Indirect Methods at Ungaged Sites}

Four bridge sites were chosen for the determination of the April 2007 peak discharge by indirect methods (Matthai, 1967; table 4):

1. Lamprey River at Epping Road railroad bridge in Raymond, N.H. (drainage area of $70 \mathrm{mi}^{2}$ );

2. Souhegan River at Wilton Road (Elm Street) bridge in Milford, N.H., approximately 2,000 ft east of the Wilton/Milford, N.H. town line (drainage area of $\left.102 \mathrm{mi}^{2}\right)$;

3. Suncook River at Short Falls Road bridge in Epsom, N.H. (drainage area of $210 \mathrm{mi}^{2}$ ); and

4. Suncook River at Websters Mill Road bridge at the Chichester/Pittsfield, N.H. town line (drainage area of $137 \mathrm{mi}^{2}$ ).

The four locations chosen for the indirect determination of the April 2007 peak-flood discharge have never been streamgage sites. High-water-mark information (table 6), the bridge-opening geometry, and channel and floodplain cross sections upstream and downstream from the bridge were surveyed at each of these sites and input into the USACE HEC-RAS program (2005). The discharges were iteratively selected and input into the HEC-RAS program to match the surface-elevation output and surveyed high-water marks (appendix 1, tables 1-1 to 1-4).

All four of these sites are located on rivers that have streamgage records. On the basis of the indirectly determined April 2007 flood-peak discharge at the ungaged location (by using high-water-mark data and the USACE HEC-RAS program) and the April 2007 flood-peak discharge determined for the streamgage site, a flow-frequency curve was generated for each of the four ungaged sites (table 4). To determine the flow-frequency curve at the ungaged site, the relation between the April 2007 peaks and drainage areas at the gaged and ungaged sites was determined. After this relation was determined, it was applied to the log-Pearson Type III flow- frequency curve determined at the streamgage site to ascertain the flow-frequency curve at the ungaged site. For comparison purposes, flow-frequency curves at all four sites also were computed by using the regression equations for estimating flow frequency developed by LeBlanc (1978) (table 4).

The coefficient $n$ in the equation below was determined through a drainage-area relation between the April 2007 flood peak discharge at the streamgage site and the indirectly determined April 2007 peak discharge at the ungaged site on each of the rivers of interest by using the drainage-area relation:

$$
Q / Q_{g}=\left(A / A_{g}\right)^{n},
$$

where

$$
\begin{array}{ll}
Q & \text { is the discharge at the ungaged site, } \\
Q_{g} & \text { is the discharge at the USGS streamgage site, } \\
A & \text { is the drainage area at the ungaged site, } \\
A_{g} & \text { is the drainage area at the USGS streamgage } \\
& \text { site, and }
\end{array}
$$

The drainage areas are shown in table 1 (in back of report) for the streamgages and in table 4 for the indirect discharge-measurement sites. April 2007 peak flood discharges are shown in table 2 for the streamgage sites and in table 4 for the indirect discharge-measurement sites. The calculatedcoefficient $n$ values for each indirect discharge-measurement location and related streamgage are shown below:

1. Lamprey River between Epping Road railroad bridge in Raymond, N.H., and streamgage 01073500 near Newmarket $(n=0.79)$;

2. Souhegan River between Wilton Road bridge near the Wilton/Milford, N.H. town line and streamgage 01094000 at Merrimack $(n=0.80)$;

3. Suncook River between Short Falls Road bridge in Epsom, N.H., and streamgage 01089500 at North Chichester $(n=0.94)$; and

4. Suncook River between Websters Mill Road bridge in Chichester/Pittsfield, N.H., and streamgage 01089500 at North Chichester $(n=0.94)$. 


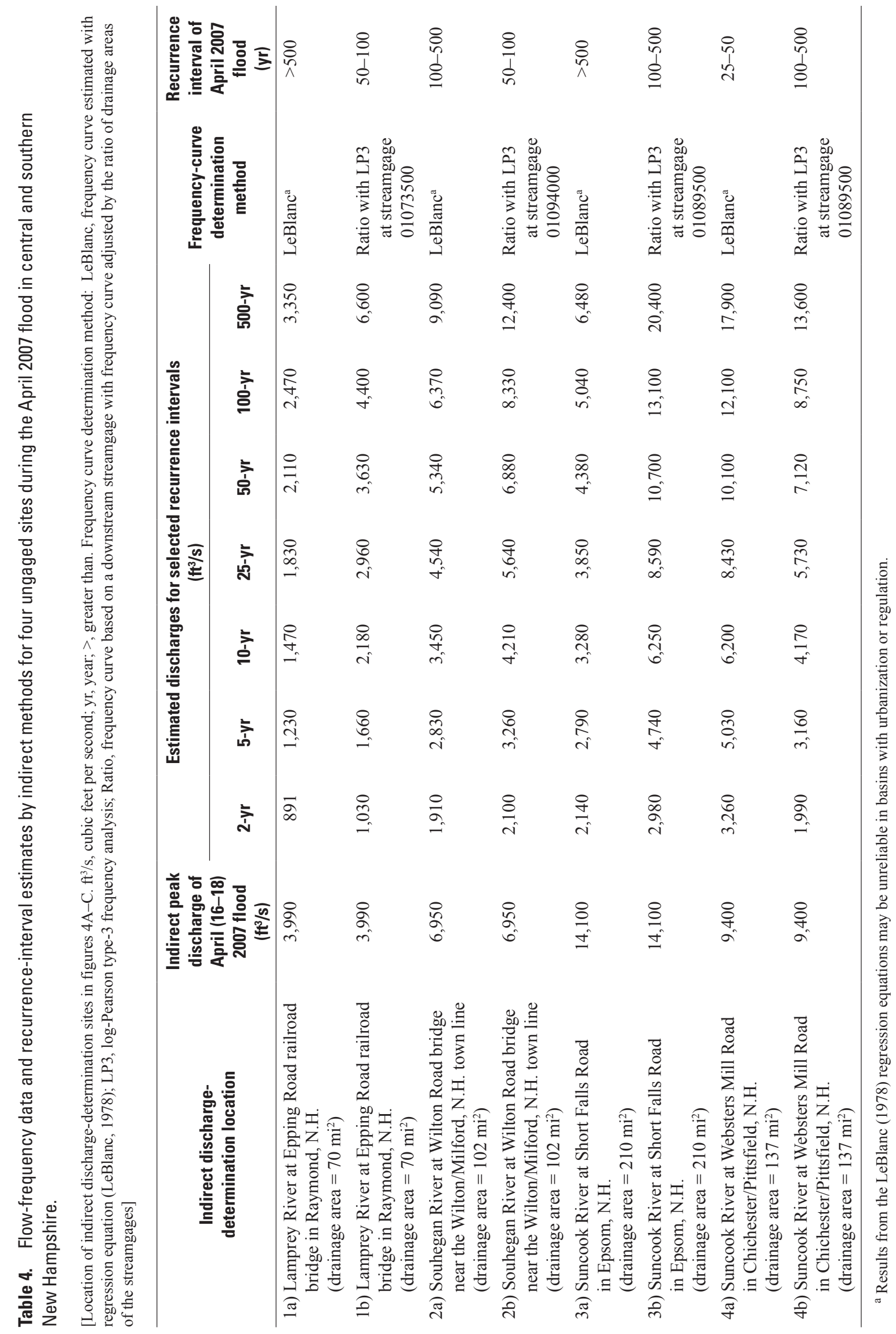




\section{Comparison of the April 2007 Flood Data to Flood-Insurance Studies}

FEMA Flood-Insurance Studies provide communities with information on the severity of flood hazards. This information includes estimated discharges and water-surfaceelevation profiles for the 10-, 50-, 100-, and 500-year floods for selected potential surface-water bodies around which development has occurred or is expected to occur. The 10-, 50-, 100-, and 500-year floods have a 10-, 2-, 1-, and 0.2-percent chance, respectively, of being equaled or exceeded in any given year. These data are used for planning purposes and for setting flood-insurance rates for structures within communities participating in the National Flood-Insurance Program.

For the streamgage and indirect-discharge sites in this study that were included in a Flood-Insurance Study, discharges and peak water-surface elevations (stage) were compiled from the appropriate study and are given in table 5. Flood-Insurance Study recurrence-interval discharges were obtained from the "Summary of Discharges" table for the reach that incorporated the streamgage site, and the peak water-surface elevations were extracted from the watersurface-elevation profiles. In cases where the streamgage site was not identified on the water-surface-elevation profiles, interpretation of the streamgage location was required to obtain the water-surface-elevation for the corresponding recurrence interval.
The compiled Flood-Insurance Study data are shown in table 5 along with the peak-stage and peak-discharge data for the April 2007 flood. The flow-frequency data obtained from the Flood-Insurance Studies (table 5) often differ from the flow-frequency data determined for this investigation (table 3) because the methods used for determining the frequency curves may be different, and (or) more data are currently available for the development of the frequency curves.

The data contained in this report may aid in the updating of future Flood-Insurance Study water-surface-elevation profiles for some communities through FEMA's Map Modernization program. For instance, at the Piscataquog River near Goffstown streamgage (01091500), the peak discharge in April 2007 was 11,200 ft $3 / \mathrm{s}$. The recurrence interval for this discharge, as reported in the Goffstown Flood-Insurance Study (Federal Emergency Management Agency, 1978b), is 50 to 100 years. It would be expected that the peak stage in April 2007 also would fall between the 50- and 100-year water-surface-elevation profiles at this location. However, the peak stage for the April 2007 flood was $187.70 \mathrm{ft}$ (NGVD 29), which is greater than the 100 -year water-surface elevation reported in the Goffstown Flood-Insurance Study. There are 16 streamgage sites and 1 indirect discharge site for which the observed peak discharge of the April 2007 flood is bracketed by a recurrence interval different than the Flood-Insurance Study recurrence interval that brackets the observed peak April 2007 flood stage or water-surface elevation (table 5). The reasons for these discrepancies are beyond the scope of this study. 


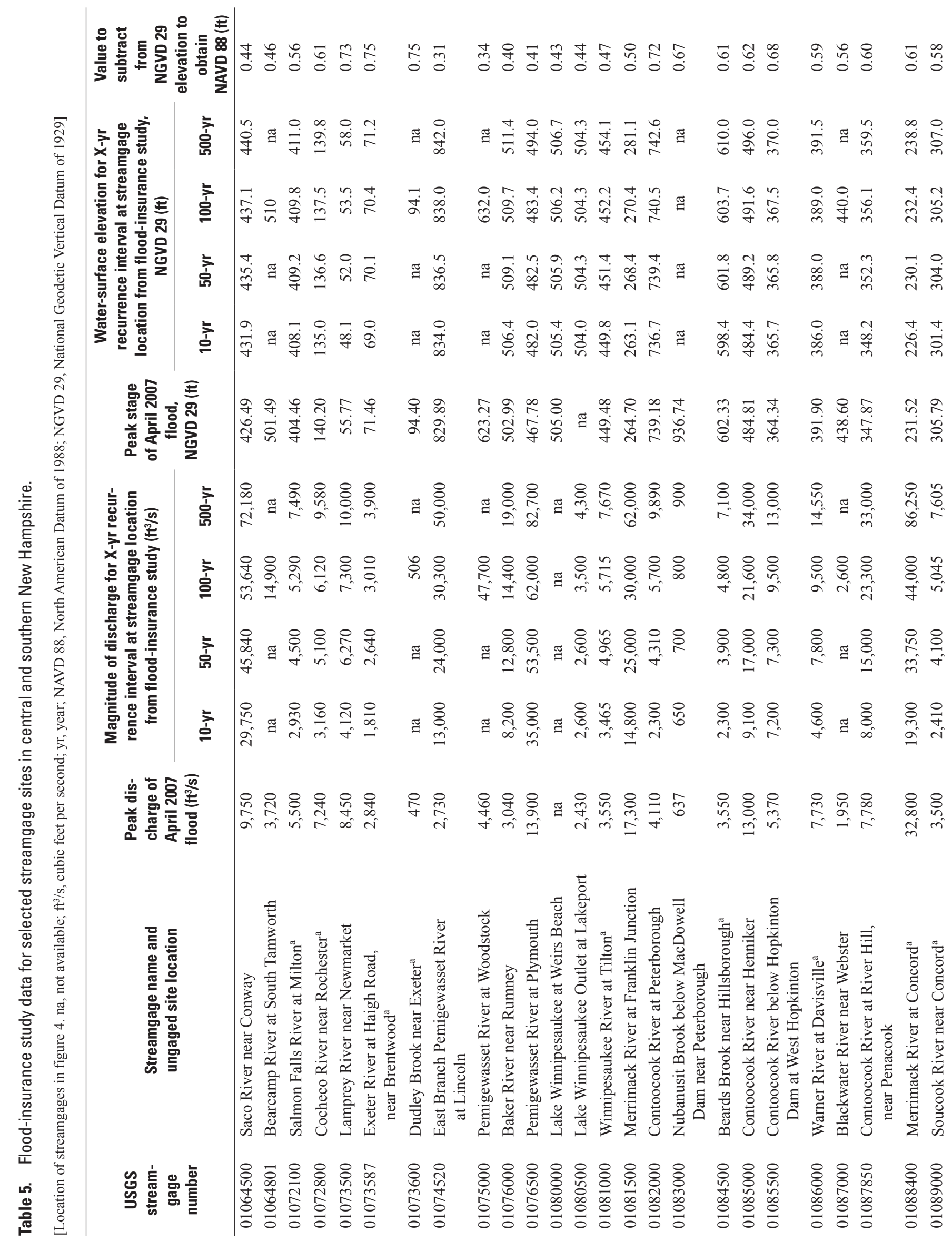




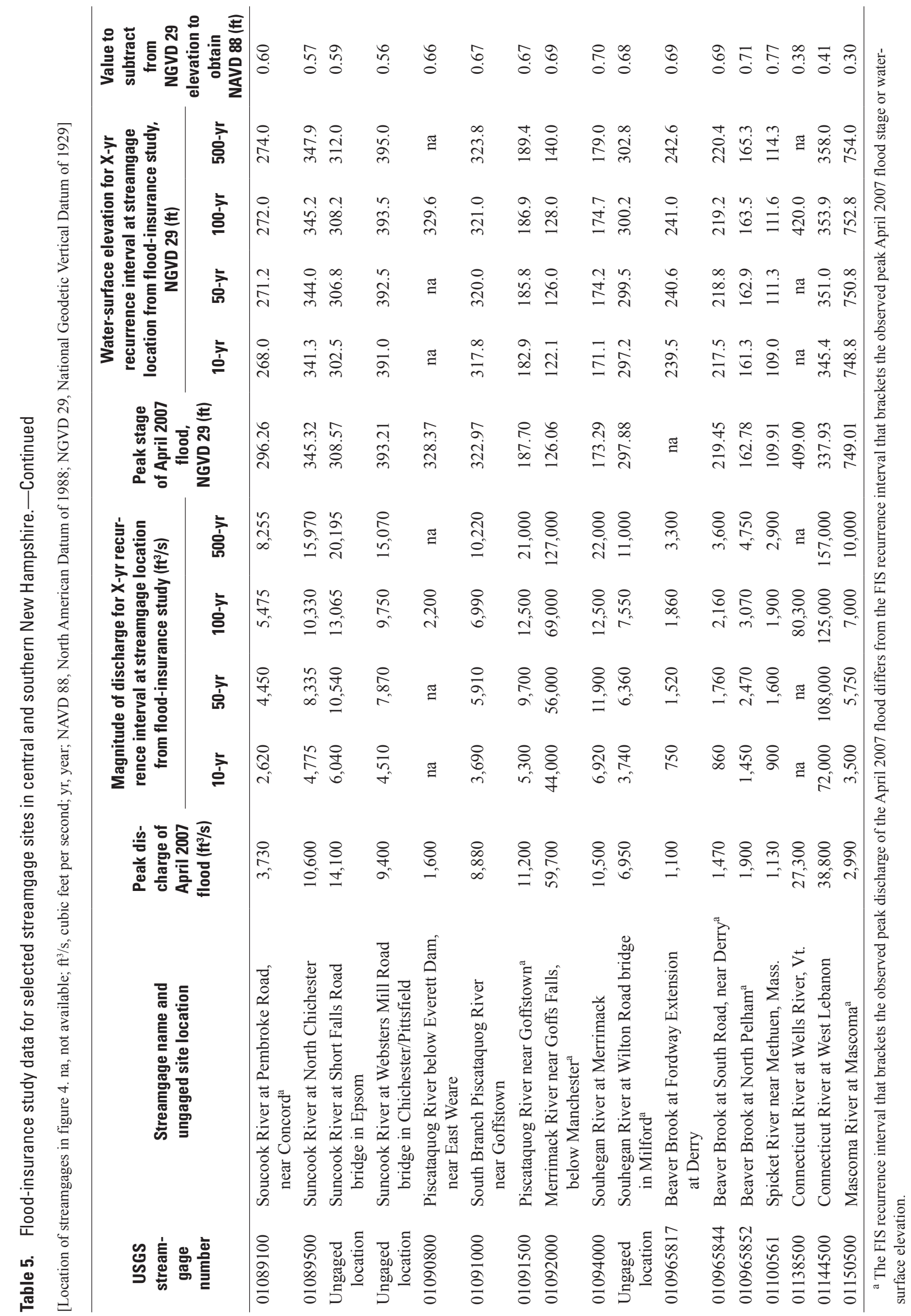




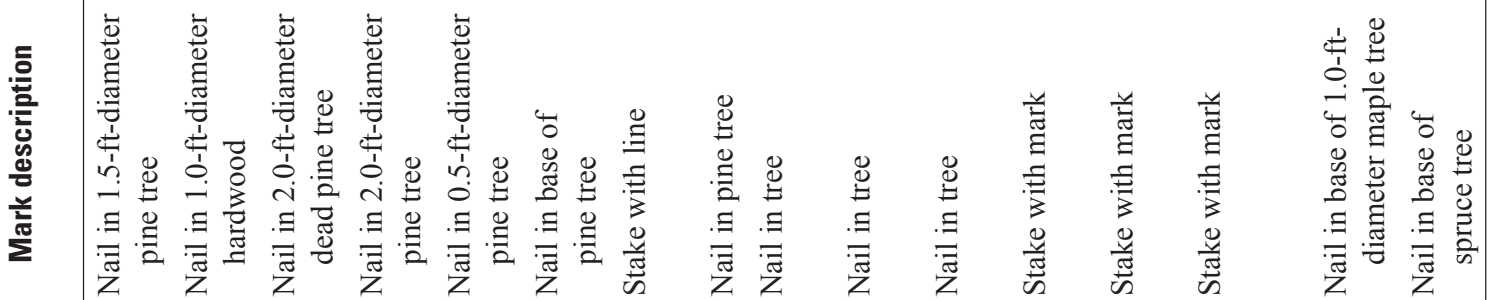

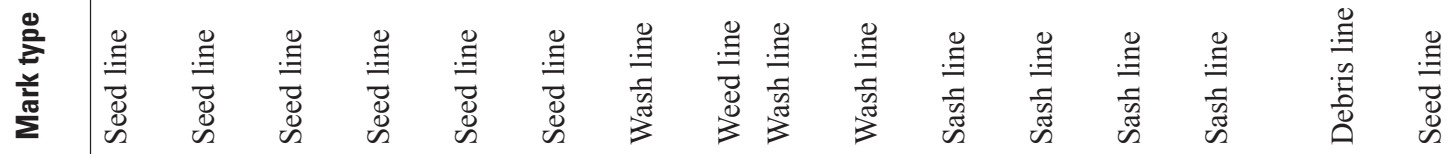

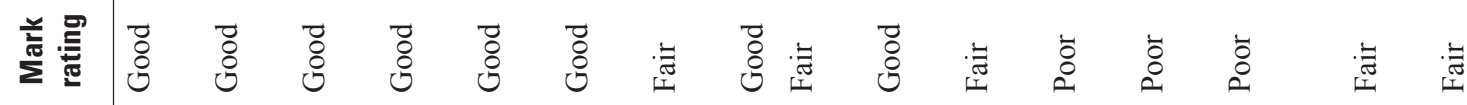

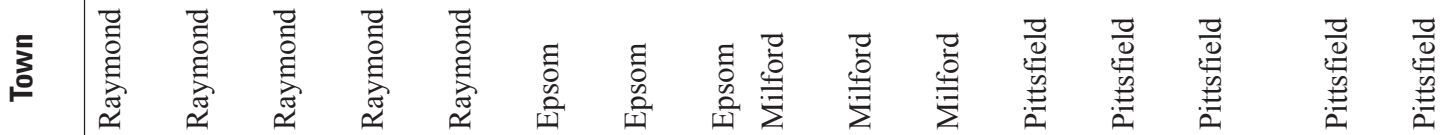

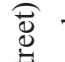

西

马

兽离

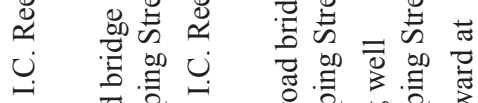

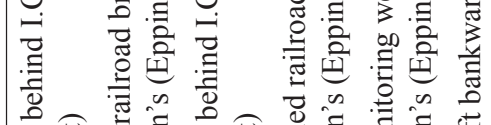



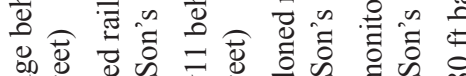

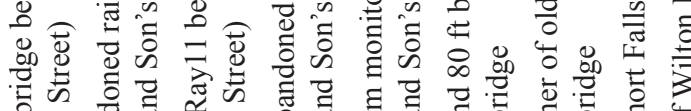

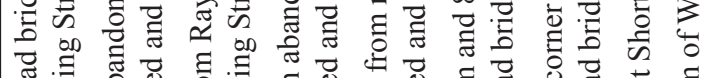

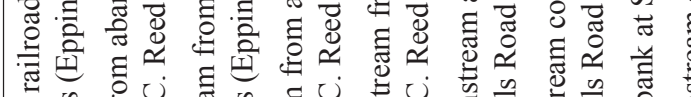

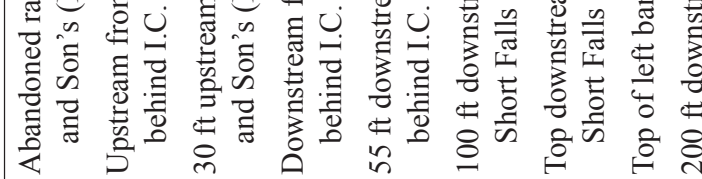

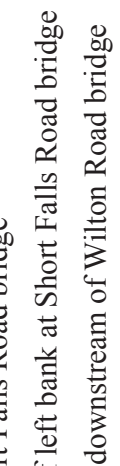

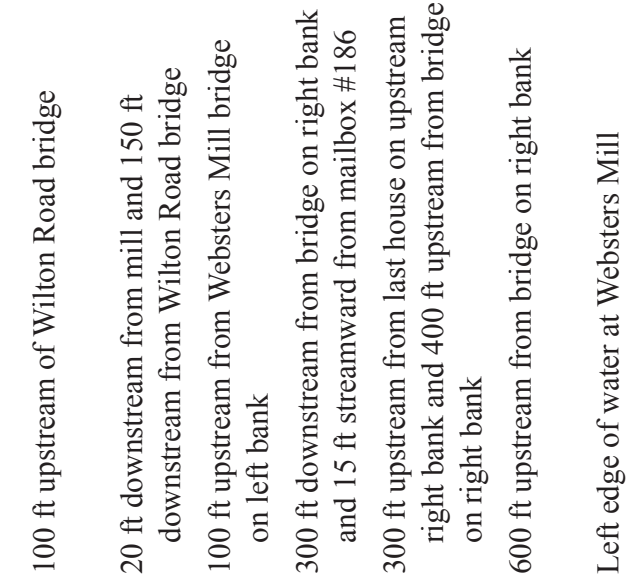

离 导

गे गे वे बे

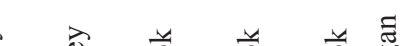

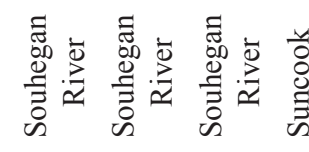

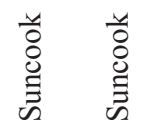

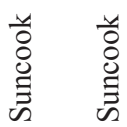

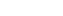

\section{墨善}

茪

$\subseteq$

$$
\text { n }- \text { a }
$$$$
\text { i }
$$

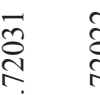

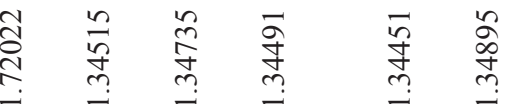

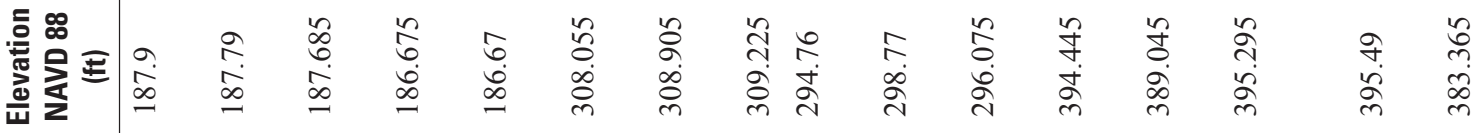




\section{Summary}

During April 16-18, 2007, central and southern New Hampshire experienced severe flooding caused by as much as $7 \mathrm{in}$. of rainfall in the region. A Presidential Disaster Declaration was issued on April 27, 2007, for five counties (Grafton, Hillsborough, Merrimack, Rockingham, and Strafford) in New Hampshire. On May 10, 2007, a sixth county (Belknap) was added to the disaster declaration. The U.S. Geological Survey, in a cooperative investigation with the Federal Emergency Management Agency (FEMA), measured or computed flood data at 57 streamgages and 4 ungaged sites in and adjacent to the counties declared disaster areas. These data include peak stages, peak discharges, and recurrence-interval estimates for the April 2007 flooding, and data compiled from FEMA Flood-Insurance Studies for comparison purposes.

The total precipitation that occurred during April 15-19, 2007, in southeastern New Hampshire (6.54 in. in Durham) is approximately one-half of the 13 in. of precipitation that fell during October 20-22, 1996, in the same area (National Oceanic and Atmospheric Administration, 1996). The total April 15-19, 2007, precipitation in southeastern New Hampshire is less than one-half of the up to 14 in. of precipitation that fell during May 11-15, 2006, across the coastal regions of New Hampshire (National Oceanic and Atmospheric Administration, 2006a) and approximately 60 percent of the up to 11 in. of precipitation that fell during May 11-15, 2006, in the south-central part of the state (National Oceanic and Atmospheric Administration, 2006b). Although the April 2007 storm produced less precipitation than either the October 1996 or May 2006 storm events, some streams in New Hampshire had higher discharges in the 2007 event. The higher than normal precipitation from the April 2007 storm, including precipitation on top of snowpack at higher elevations, downed trees, and wood debris in some rivers contributed to the high flows and flooding in southern and central New Hampshire. In addition, an abnormally high spring tide along with a storm surge of nearly $3 \mathrm{ft}$ caused tidal flooding along portions of the seacoast (National Oceanic and Atmospheric Administration, 2007b), and the prolonged period of strong northeast winds caused a prolonged storm surge along the coastline (National Climate Data Center, 2007).

At 5 long-term (more than 10 years of record) streamgage sites, the peak discharge in April 2007 was the maximum discharge for the period of record. These streamgages include South Branch Piscataquog River near Goffstown (1941-78), Contoocook River at Peterborough, 1946-present (2008); Oyster River near Durham, 1934-present (2008); Cocheco River near Rochester, 1995-present (2008); and Salmon Falls River at Milton, 1968-present (2008).

Peak discharges equaled or exceeded a 100-year recurrence interval at 10 streamgages and equaled or exceeded a 50 -year recurrence interval at 16 streamgages. The most severe flooding was in Rockingham, Strafford, Merrimack, and Hillsborough Counties.

Peak-flood discharge and stage data from the April 2007 flood event at streamgage and indirect-discharge sites were compared to recurrence-interval discharges and peak watersurface elevations (stage) determined by Flood-Insurance Studies, where available. Flood-Insurance Study recurrenceinterval discharges were obtained from the "Summary of Discharges" table for the reach that incorporated the streamgage site, and the peak water-surface elevations were extracted from the water-surface-elevation profiles. In cases where the streamgage site was not identified on the watersurface-elevation profiles, interpretation of the streamgage location was required to obtain the water-surface-elevation for the corresponding recurrence interval.

\section{Selected References}

Benson, M.A., and Dalrymple, Tate, 1967, General field and office procedures for indirect discharge measurements: U.S. Geological Survey Techniques of Water-Resources Investigations, book 3, chap. A1, 30 p.

Federal Emergency Management Agency, 1977, Floodinsurance study, Town of Henniker, Merrimack County, New Hampshire: Washington, D.C., 15 p.

Federal Emergency Management Agency, 1978a, Floodinsurance study, Town of Chichester, Merrimack County, New Hampshire: Washington, D.C., 15 p.

Federal Emergency Management Agency, 1978b, Floodinsurance study, Town of Goffstown, Hillsborough County, New Hampshire: Washington, D.C., 18 p.

Federal Emergency Management Agency, 1978c, Floodinsurance study, Town of Hillsborough, Hillsborough County, New Hampshire: Washington, D.C., 20 p.

Federal Emergency Management Agency, 1979a, Floodinsurance study, City of Franklin, Merrimack County, New Hampshire: Washington, D.C., 20 p.

Federal Emergency Management Agency, 1979b, Floodinsurance study, Town of Merrimack, Hillsborough County, New Hampshire: Washington, D.C., 27 p.

Federal Emergency Management Agency, 1979c, Floodinsurance study, Town of Pelham, Hillsborough County, New Hampshire: Washington, D.C., 22 p.

Federal Emergency Management Agency, 1979d, Floodinsurance study, Town of Peterborough, Hillsborough County, New Hampshire: Washington, D.C., 21 p. 
Federal Emergency Management Agency, 1979e, Floodinsurance study, Town of Milford, Hillsborough County, New Hampshire: Washington, D.C., 22 p.

Federal Emergency Management Agency, 1980a, Floodinsurance study, City of Laconia, Belknap County, New Hampshire: Washington, D.C., 24 p.

Federal Emergency Management Agency, 1980b, Floodinsurance study, City of Manchester, Hillsborough County, New Hampshire: Washington, D.C., 24 p.

Federal Emergency Management Agency, 1987, Floodinsurance study, Town of Warner, Merrimack County, New Hampshire: Washington, D.C., 18 p.

Federal Emergency Management Agency, 1988, Floodinsurance study, Town of Hopkinton, Merrimack County, New Hampshire: Washington, D.C., 16 p.

Federal Emergency Management Agency, 1991, Floodinsurance study, Town of Tamworth, Carroll County, New Hampshire: Washington, D.C., 12 p.

Federal Emergency Management Agency, 1993a, Floodinsurance study, Town of Weare, Hillsborough County, New Hampshire: Washington, D.C., 16 p.

Federal Emergency Management Agency, 1993b, Floodinsurance study, Town of Webster, Merrimack County, New Hampshire: Washington, D.C., 10 p.

Federal Emergency Management Agency, 1997, Floodinsurance study, Town of Tilton, Belknap County, New Hampshire: Washington, D.C., 20 p.

Federal Emergency Management Agency, 1999, Floodinsurance study, City of Concord, Merrimack County, New Hampshire: Washington, D.C., 20 p.

Federal Emergency Management Agency, 2001, Floodinsurance study, Town of New Boston, Hillsborough County, New Hampshire: Washington, D.C., 18 p.

Federal Emergency Management Agency, 2002, Floodinsurance study, Town of Conway, Carroll County, New Hampshire: Washington, D.C., 21 p.

Federal Emergency Management Agency, 2005a, FloodInsurance Study, Rockingham County, New Hampshire, all jurisdictions: Washington, D.C., 87 p.

Federal Emergency Management Agency, 2005b, Floodinsurance study, Strafford County, New Hampshire, all jurisdictions: Washington, D.C., 41 p.

Federal Emergency Management Agency, 2007, Initial notices and amendments, New Hampshire severe storms and flooding: Initial Notice and Amendments No. 1 and 2, accessed December 27, 2007, at http://www.fema.gov/news/eventdfrns.fema?id=7906
Federal Emergency Management Agency, 2008, Floodinsurance study, Grafton County, New Hampshire, all jurisdictions: Washington, D.C., 79 p.

LeBlanc, D.R., 1978, Progress report on hydrologic investigations of small drainage areas in New HampshirePreliminary relations for estimating peak discharge on rural, unregulated streams: U.S. Geological Survey WaterResources Investigations Report 78-47, 9 p.

Leica Geosystems, 2008, Leica GPS1200, GPS1200 surveying systems, accessed November 9, 2007, at http://www. leica-geosystems.com/corporate/en/products/total_stations/ lgs_4521.htm

Matthai, H.F., 1967, Measurement of peak discharge at width contractions by indirect methods: Techniques of WaterResources Investigations, book 3, chap. A4, 44 p.

National Climate Data Center, 2007, Storm events data base, accessed December 27, 2007, at http://www4.ncdc.noaa. gov/cgi-win/wwcgi.dll?wwEvent $\sim$ Storms

National Climate Data Center, 2008, Normal precipitation, inches, accessed February 19, 2008, at http://www.ncdc. noaa.gov/oa/climate/online/ccd/nrmpcp.txt

National Oceanic and Atmospheric Administration, 1996, Climatological data-New England, October 1996: Climatological Data, v. 108, no. 10, 46 p.

National Oceanic and Atmospheric Administration, 2006a, Record of climatological observations (COOP), accessed November 17, 2006, at http://www7.ncdc.noaa.gov/IPS/ coopgetpublications.html

National Oceanic and Atmospheric Administration, 2006b, Public information statement, accessed November 17, 2006, at http://www.ncdc.noaa.gov/oa/climate/research/2006/may/ boxpns.txt

National Oceanic and Atmospheric Administration, 2007a, Record of climatological observations (COOP), accessed December 27, 2007, at http://www1.ncdc.noaa.gov/pub/ orders/7A7D76FF-CE3F-4DDD-0A85-6A86CFEDA9E8. PDF

National Oceanic and Atmospheric Administration, 2007b, Public information statement, accessed December 27, 2007, at http://www.srh.noaa.gov/productview. php?pil $=$ CLMCON\&version $=7 \& \max =61$

Northeast River Forecast Center, 2007a, 1-day observed precipitation-Valid April 16-18, 2006, 1200 UTC, accessed December 27, 2007, at http://www.erh.noaa.gov/ nerfc/obsprecip.shtml 
Northeast River Forecast Center, 2007b, New Hampshire: April 2007 monthly observed precipitation, accessed December 27, 2007, at http://www.srh.noaa.gov/rfcshare/ precip_analysis_new.php?location $=\operatorname{tar} \&$ overlay $=1100101$

Olson, S.A., 2007, Flood of May 2006 in New Hampshire: U.S. Geological Survey Open-File Report 2007-1122, 32 p.

U.S. Army Corps of Engineers, May 2005, HEC-RAS river analysis system, Version 3.1.3: Hydrologic Engineering Center, accessed September 2, 2007, at http://www.hec. usace.army.mil

U.S. Army Corps of Engineers, 2007, New England District Corp of Engineers reservoir regulation team, accessed September 8, 2007, at https://rsgis.crrel.usace.army.mil/nae/ pls/nae/nae_web.nae_webmenu.displaymenu?menu=hydro
U.S. Geological Survey, 2007a, Water resources application software, PeakFQ, accessed October 12, 2007, at http://water.usgs.gov/software/peakfq.html

U.S. Geological Survey, 2007b, Peak streamflow for New Hampshire: National Water Information System, accessed October 12, 2007, at http://nwis.waterdata.usgs. gov/nh/nwis/peak

U.S. Interagency Advisory Committee on Water Data, 1982, Guidelines for determining flood flow frequency, Bulletin 17-B of the Hydrology Subcommittee: Reston, Va., U.S. Geological Survey, Office of Water Data Coordination, $183 \mathrm{p}$. 


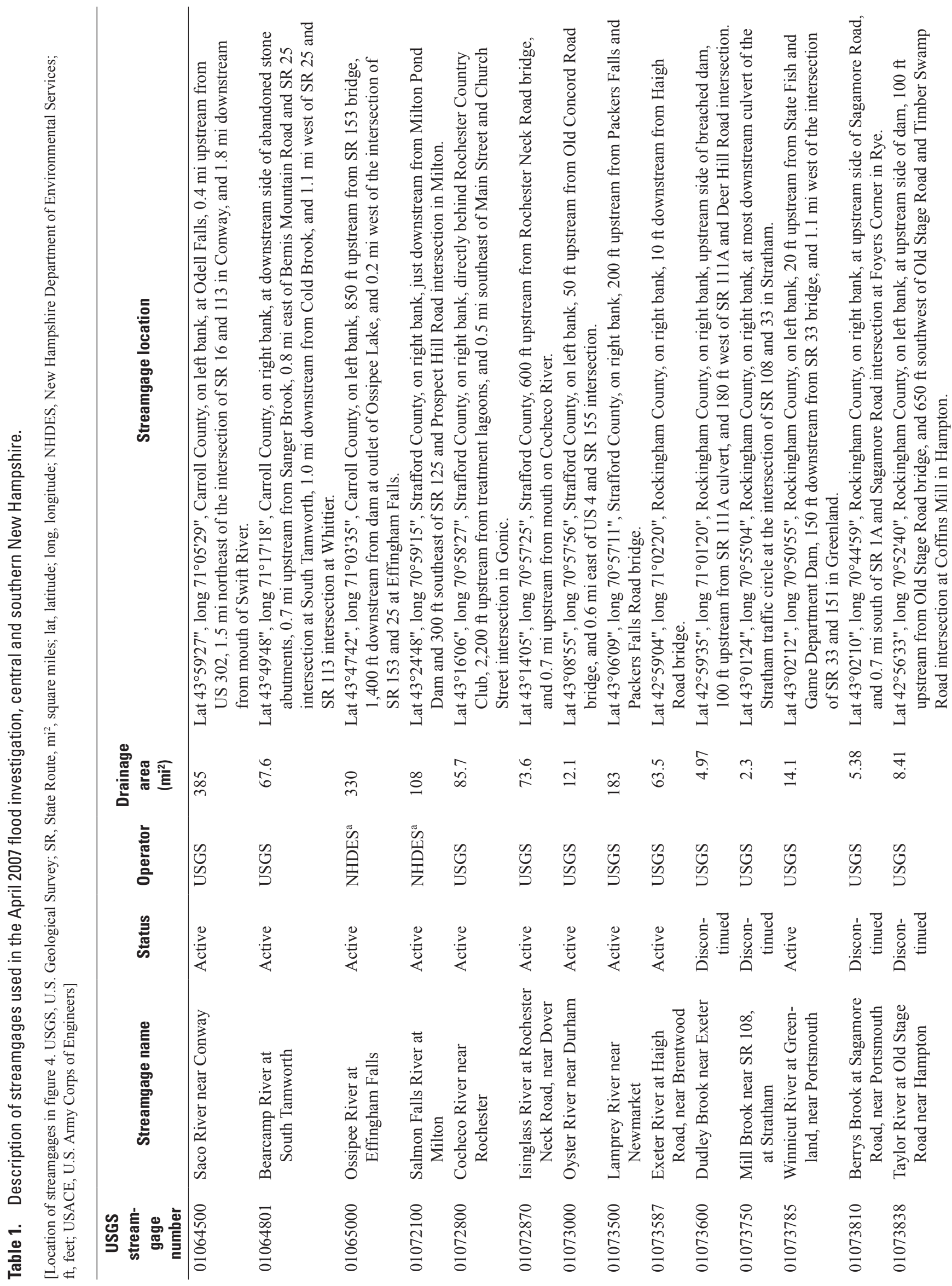




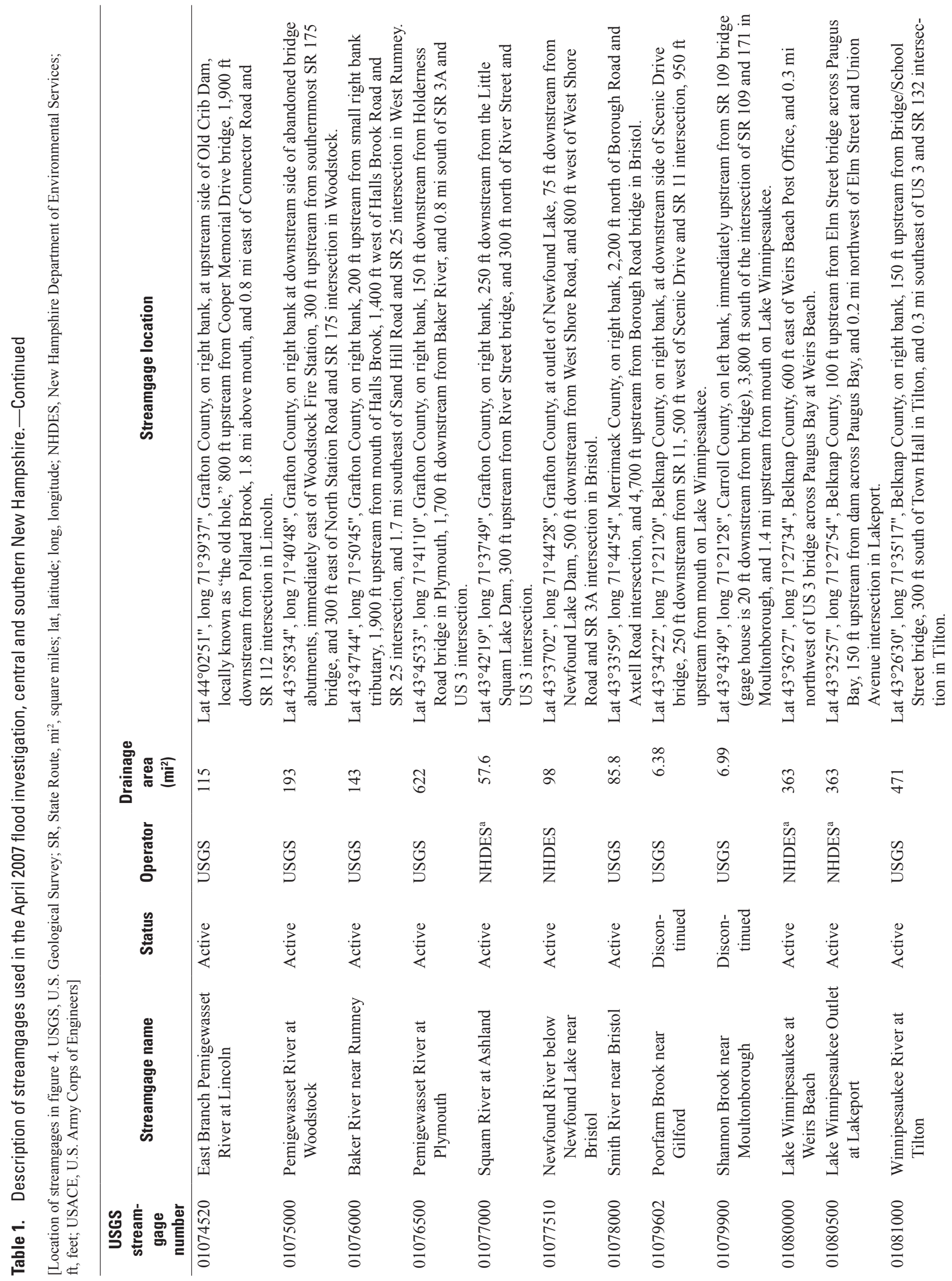




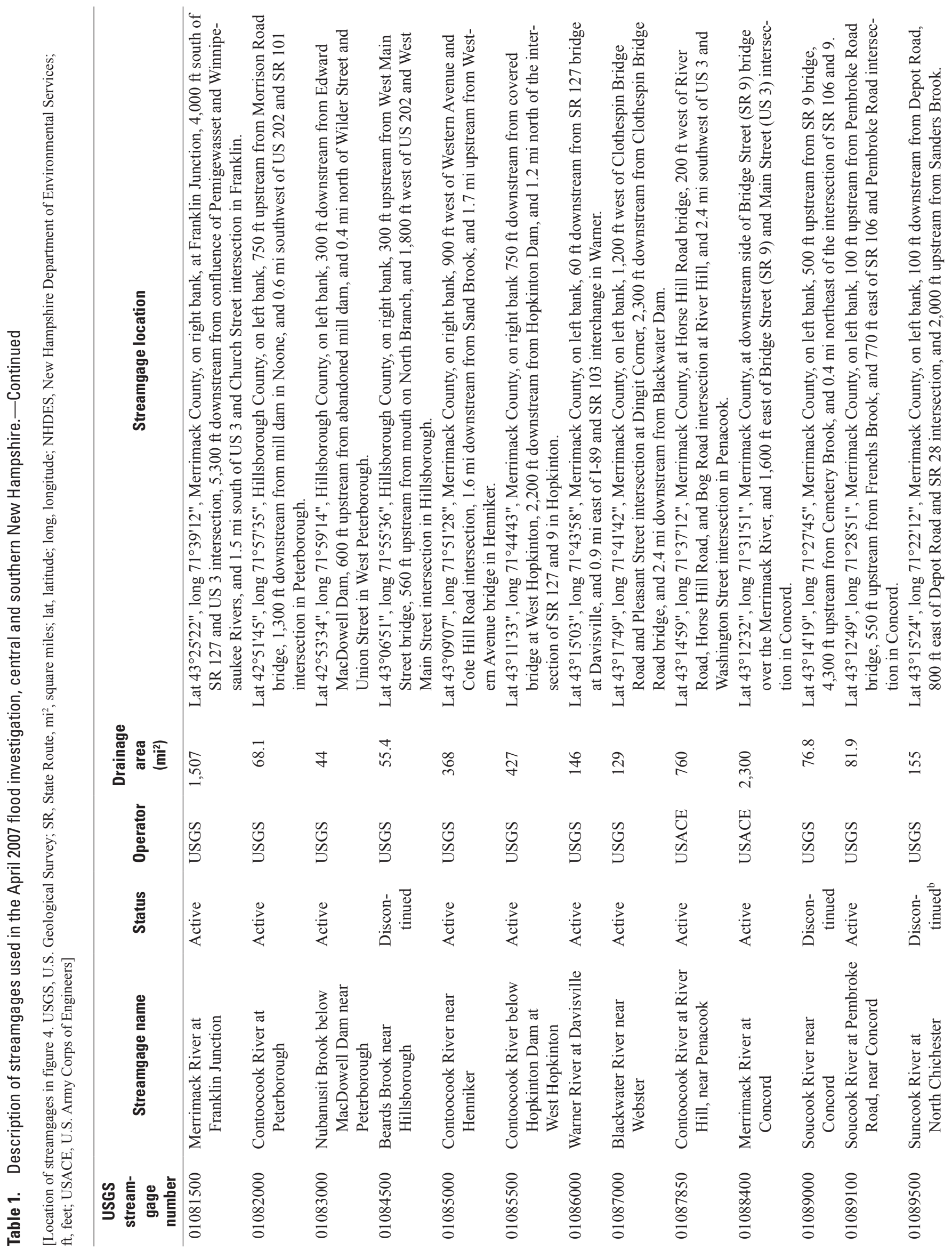




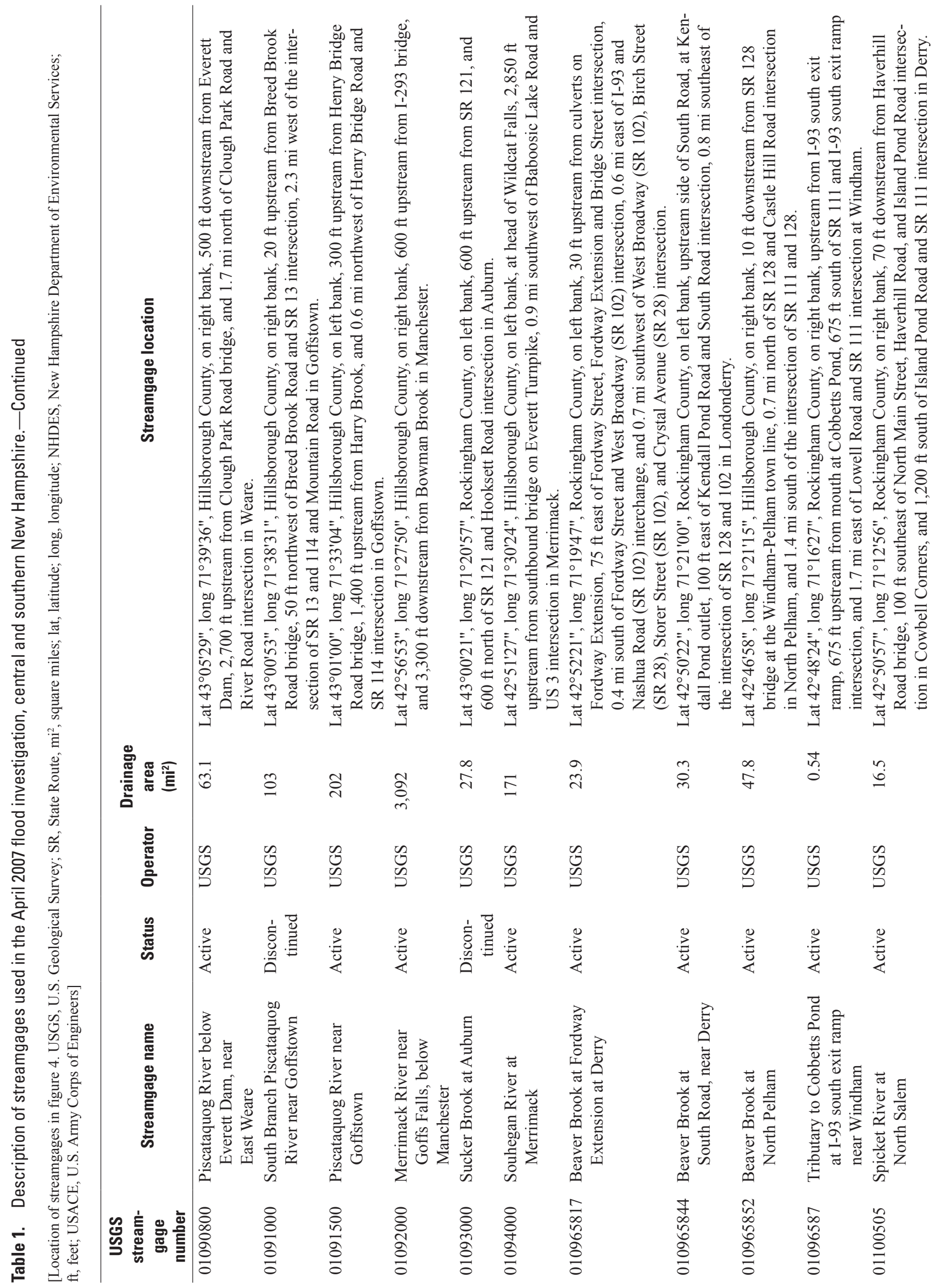




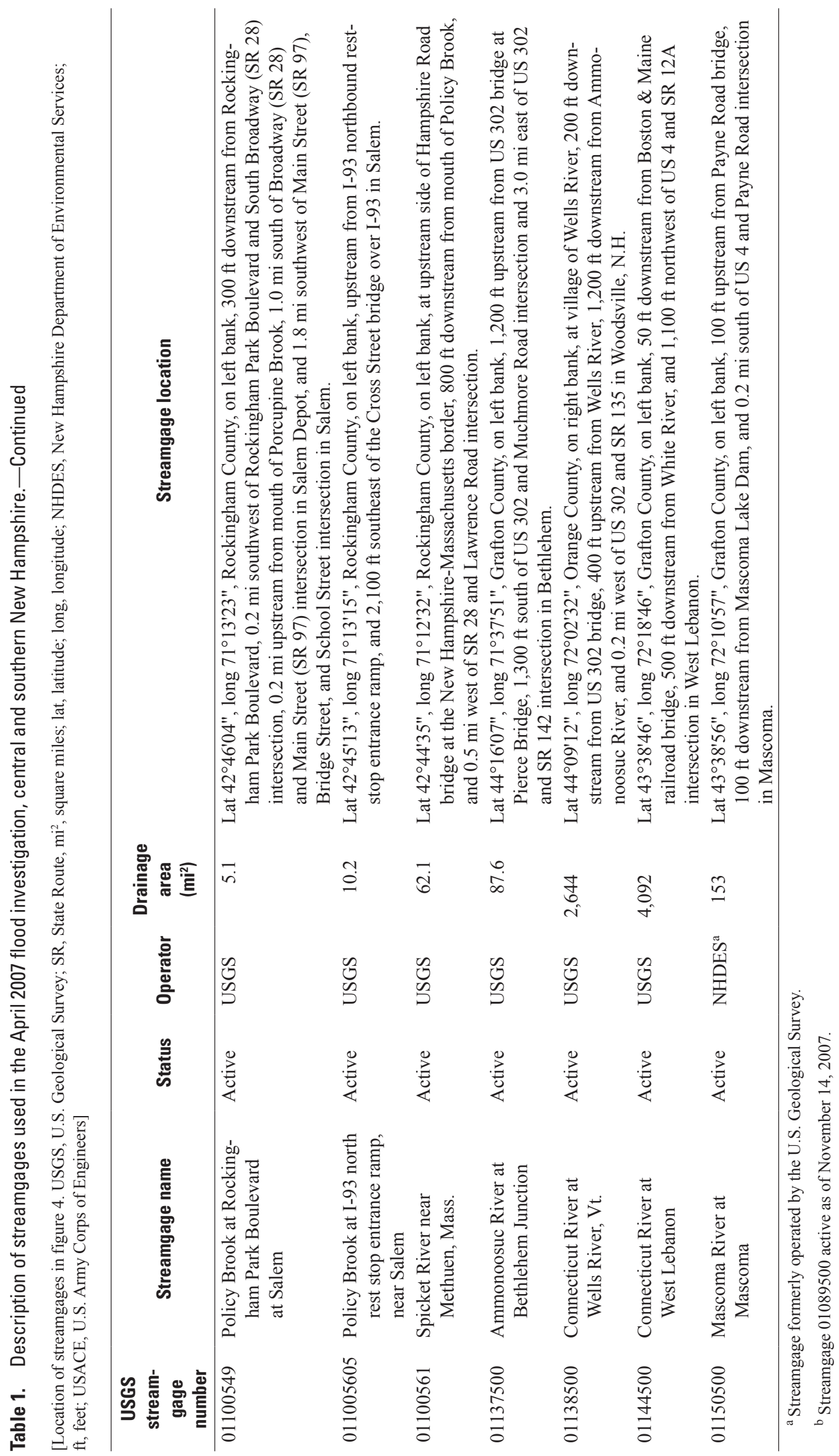





\section{Appendix 1. HEC-RAS Model Calibrations to Estimate the April 2007 Flood-Peak Discharge from High-Water-Mark Data Collected for the Lamprey, Souhegan, and Suncook Rivers}

\section{Tables}

1-1. HEC-RAS model calibration to estimate the April 2007 Lamprey River flood-peak discharge from high-water-mark data collected at the railroad bridge upstream of Epping Road in Raymond, New Hampshire.

1-2. HEC-RAS model calibration to estimate the April 2007 Souhegan River flood-peak discharge from high-water-mark data collected at the Wilton Road (Elm Street) bridge in Milford, New Hampshire.

1-3. HEC-RAS model calibration to estimate the April 2007 Suncook River flood-peak discharge from high-water-mark data collected at the Short Falls Road bridge in Epsom, New Hampshire

1-4. HEC-RAS model calibration to estimate the April 2007 Suncook River flood-peak discharge from high-water-mark data collected at the Websters Mill Road bridge in Chichester/Pittsfield, New Hampshire. 
Table 1-1. HEC-RAS model calibration to estimate the April 2007 Lamprey River flood-peak discharge from high-water-mark data collected at the railroad bridge upstream of Epping Road in Raymond, New Hampshire.

[River station locations are indicated by an arbitrary cross-section numbering system and are not shown on any figure. $\mathrm{ft}$, feet; ft $\mathrm{ft}^{3} / \mathrm{s}$, cubic feet per second]

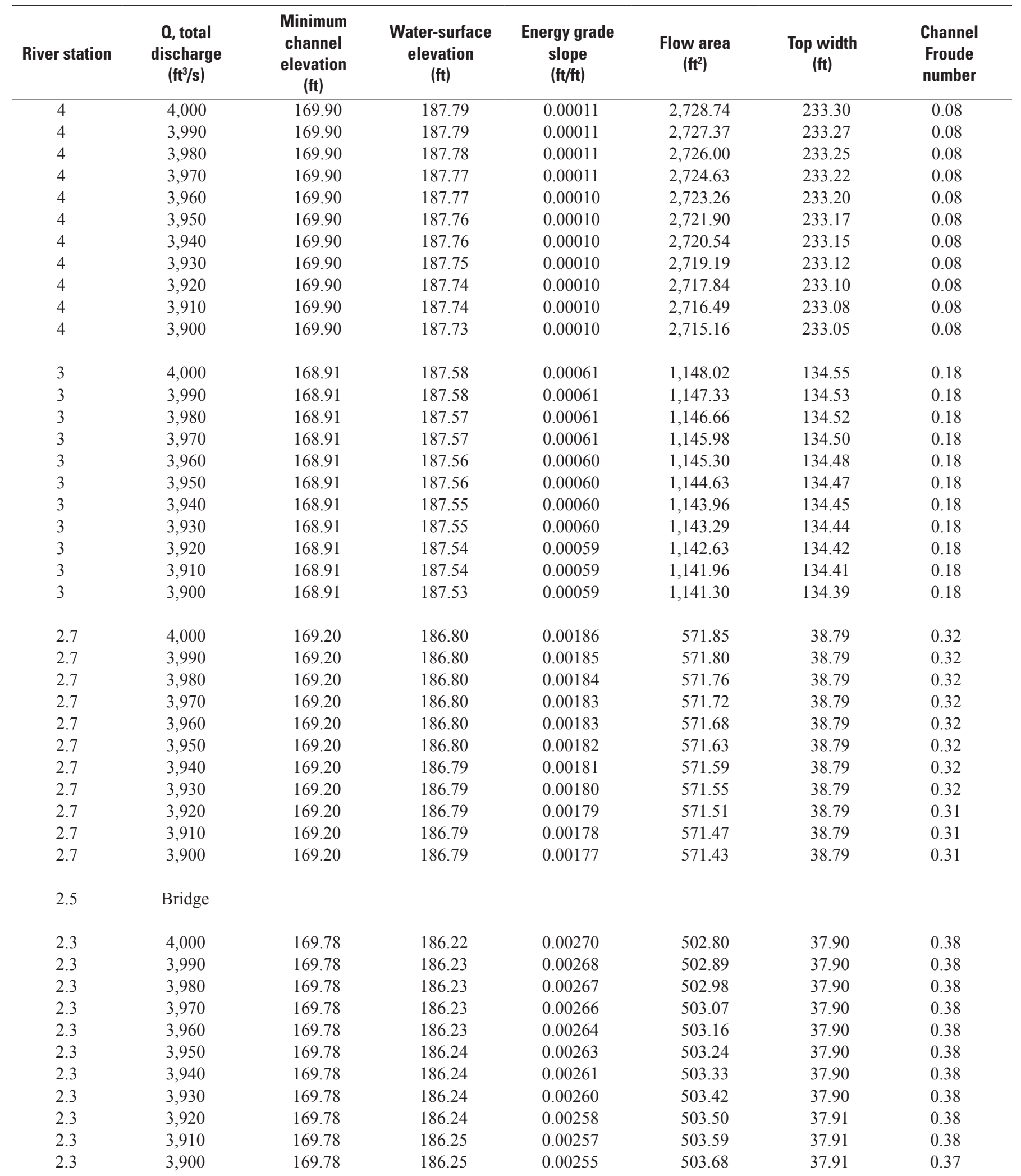


Table 1-1. HEC-RAS model calibration to estimate the April 2007 Lamprey River flood-peak discharge from high-water-mark data collected at the railroad bridge upstream of Epping Road in Raymond, New Hampshire.-Continued

[River station locations are indicated by an arbitrary cross-section numbering system and are not shown on any figure. $\mathrm{ft}$, feet; $\mathrm{ft}^{3} / \mathrm{s}$, cubic feet per second]

\begin{tabular}{|c|c|c|c|c|c|c|c|}
\hline River station & $\begin{array}{c}\text { Q, total } \\
\text { discharge } \\
\left(\mathrm{ft}^{3} / \mathbf{s}\right)\end{array}$ & $\begin{array}{l}\text { Minimum } \\
\text { channel } \\
\text { elevation } \\
\text { (ft) }\end{array}$ & $\begin{array}{c}\text { Water-surface } \\
\text { elevation } \\
\text { (ft) }\end{array}$ & $\begin{array}{l}\text { Energy grade } \\
\text { slope } \\
\text { (ft/ft) }\end{array}$ & $\begin{array}{c}\text { Flow area } \\
\left(\mathrm{ft}^{2}\right)\end{array}$ & $\begin{array}{l}\text { Top width } \\
\text { (ft) }\end{array}$ & $\begin{array}{c}\text { Channel } \\
\text { Froude } \\
\text { number }\end{array}$ \\
\hline 2 & 3,990 & 165.71 & 186.67 & 0.00006 & $3,064.41$ & 280.06 & 0.08 \\
\hline 2 & 3,980 & 165.71 & 186.67 & 0.00006 & $3,064.40$ & 280.06 & 0.08 \\
\hline 2 & 3,970 & 165.71 & 186.67 & 0.00006 & $3,064.39$ & 280.06 & 0.08 \\
\hline 2 & 3,950 & 165.71 & 186.67 & 0.00006 & $3,064.37$ & 280.06 & 0.08 \\
\hline 2 & 3,940 & 165.71 & 186.67 & 0.00006 & $3,064.36$ & 280.06 & 0.08 \\
\hline 2 & 3,930 & 165.71 & 186.67 & 0.00006 & $3,064.35$ & 280.06 & 0.08 \\
\hline 2 & 3,920 & 165.71 & 186.67 & 0.00006 & $3,064.34$ & 280.05 & 0.08 \\
\hline 2 & 3,910 & 165.71 & 186.67 & 0.00006 & $3,064.33$ & 280.05 & 0.08 \\
\hline 2 & 3,900 & 165.71 & 186.67 & 0.00006 & $3,064.32$ & 280.05 & 0.07 \\
\hline 1 & 3,980 & 171.11 & 186.66 & 0.00028 & $3,115.09$ & 362.46 & 0.10 \\
\hline 1 & 3,970 & 171.11 & 186.66 & 0.00028 & $3,115.09$ & 362.46 & 0.10 \\
\hline 1 & 3,960 & 171.11 & 186.66 & 0.00028 & $3,115.09$ & 362.46 & 0.10 \\
\hline 1 & 3,950 & 171.11 & 186.66 & 0.00028 & $3,115.09$ & 362.46 & 0.10 \\
\hline 1 & 3,940 & 171.11 & 186.66 & 0.00028 & $3,115.09$ & 362.46 & 0.10 \\
\hline 1 & 3,930 & 171.11 & 186.66 & 0.00028 & $3,115.09$ & 362.46 & 0.10 \\
\hline 1 & 3,920 & 171.11 & 186.66 & 0.00027 & $3,115.09$ & 362.46 & 0.10 \\
\hline 1 & 3,910 & 171.11 & 186.66 & 0.00027 & $3,115.09$ & 362.46 & 0.10 \\
\hline 1 & 3,900 & 171.11 & 186.66 & 0.00027 & $3,115.09$ & 362.46 & 0.10 \\
\hline
\end{tabular}


Table 1-2. HEC-RAS model calibration to estimate the April 2007 Souhegan River flood-peak discharge from high-water-mark data collected at the Wilton Road (Elm Street) bridge in Milford, New Hampshire.

[River station locations are indicated by an arbitrary cross-section numbering system and are not shown on any figure. $\mathrm{ft}$, feet; $\mathrm{ft}^{3} / \mathrm{s}$, cubic feet per second]

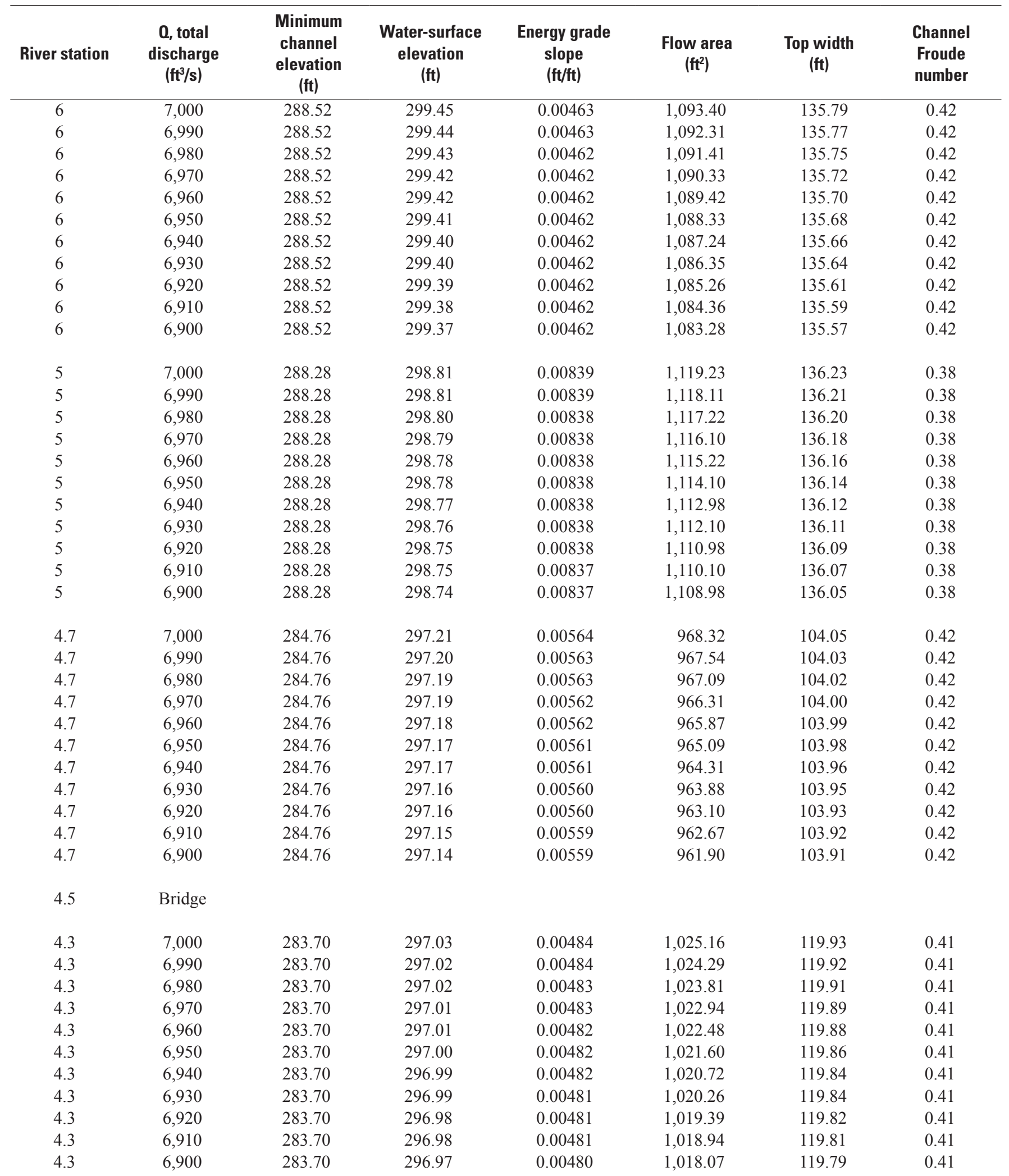


Table 1-2. HEC-RAS model calibration to estimate the April 2007 Souhegan River flood-peak discharge from high-water-mark data collected at the Wilton Road (Elm Street) bridge in Milford, New Hampshire.-Continued

[River station locations are indicated by an arbitrary cross-section numbering system and are not shown on any figure. $\mathrm{ft}$, feet; ft/s, cubic feet per second]

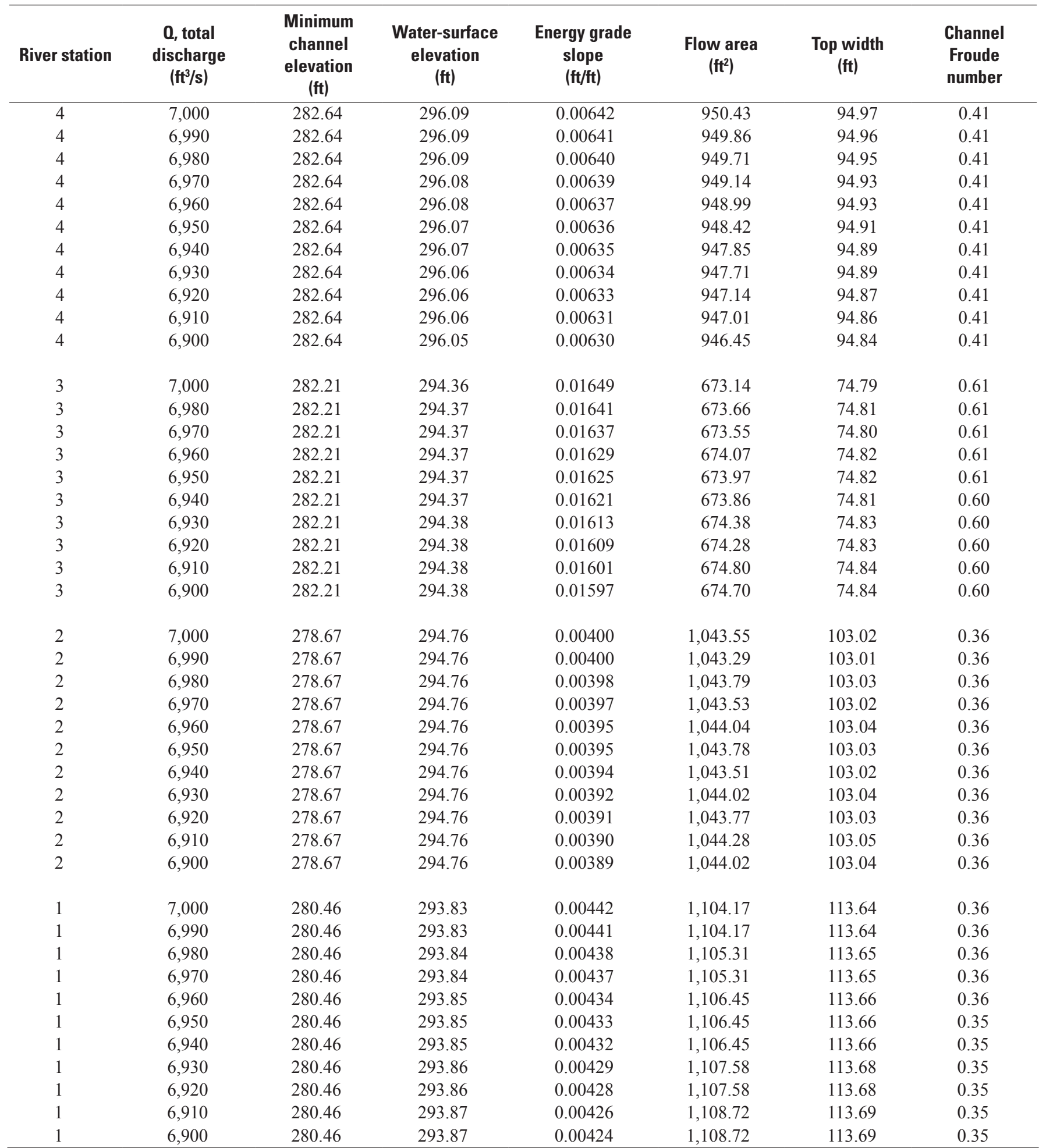


Table 1-3. HEC-RAS model calibration to estimate the April 2007 Suncook River flood-peak discharge from high-water-mark data collected at the Short Falls Road bridge in Epsom, New Hampshire.

[River station locations are indicated by an arbitrary cross-section numbering system and are not shown on any figure. $\mathrm{ft}$, feet; $\mathrm{ft}^{3} / \mathrm{s}$, cubic feet per second]

\begin{tabular}{|c|c|c|c|c|c|c|c|}
\hline River station & $\begin{array}{c}\text { 0, total } \\
\text { discharge } \\
\left(\mathrm{ft}^{3} / \mathrm{s}\right)\end{array}$ & $\begin{array}{l}\text { Minimum } \\
\text { channel } \\
\text { elevation } \\
\text { (ft) }\end{array}$ & $\begin{array}{l}\text { Water-surface } \\
\text { elevation } \\
\text { (ft) }\end{array}$ & $\begin{array}{c}\text { Energy grade } \\
\text { slope } \\
\text { (ft/ft) }\end{array}$ & $\begin{array}{l}\text { Flow area } \\
\qquad\left(\mathrm{ft}^{2}\right)\end{array}$ & $\begin{array}{l}\text { Top width } \\
\text { (ft) }\end{array}$ & $\begin{array}{l}\text { Channel } \\
\text { Froude } \\
\text { number }\end{array}$ \\
\hline 6 & 14,500 & 289.88 & 309.33 & 0.00163 & $2,016.51$ & 158.58 & 0.35 \\
\hline 6 & 14,400 & 289.88 & 309.30 & 0.00161 & $2,012.63$ & 158.37 & 0.35 \\
\hline 6 & 14,300 & 289.88 & 309.28 & 0.00160 & $2,008.81$ & 158.17 & 0.35 \\
\hline 6 & 14,200 & 289.88 & 309.25 & 0.00159 & $2,005.08$ & 157.97 & 0.35 \\
\hline 6 & 14,100 & 289.88 & 309.23 & 0.00157 & $2,001.38$ & 157.77 & 0.35 \\
\hline 6 & 14,000 & 289.88 & 309.21 & 0.00156 & $1,997.76$ & 157.58 & 0.35 \\
\hline 6 & 13,900 & 289.88 & 309.19 & 0.00154 & $1,994.20$ & 157.39 & 0.34 \\
\hline 6 & 13,800 & 289.88 & 309.16 & 0.00153 & $1,990.69$ & 157.20 & 0.34 \\
\hline 6 & 13,700 & 289.88 & 309.14 & 0.00152 & $1,987.22$ & 157.02 & 0.34 \\
\hline 6 & 13,600 & 289.88 & 309.12 & 0.00150 & $1,983.84$ & 156.84 & 0.34 \\
\hline 6 & 13,500 & 289.88 & 309.10 & 0.00149 & $1,980.50$ & 156.66 & 0.34 \\
\hline 5.5 & 14,500 & 288.33 & 309.11 & 0.00295 & $1,906.97$ & 145.14 & 0.37 \\
\hline 5.5 & 14,400 & 288.33 & 309.09 & 0.00292 & $1,903.78$ & 145.04 & 0.37 \\
\hline 5.5 & 14,300 & 288.33 & 309.07 & 0.00290 & $1,900.64$ & 144.94 & 0.37 \\
\hline 5.5 & 14,200 & 288.33 & 309.05 & 0.00287 & $1,897.57$ & 144.84 & 0.36 \\
\hline 5.5 & 14,100 & 288.33 & 309.03 & 0.00284 & $1,894.53$ & 144.74 & 0.36 \\
\hline 5.5 & 14,000 & 288.33 & 309.01 & 0.00281 & $1,891.57$ & 144.64 & 0.36 \\
\hline 5.5 & 13,900 & 288.33 & 308.99 & 0.00278 & $1,888.65$ & 144.55 & 0.36 \\
\hline 5.5 & 13,800 & 288.33 & 308.97 & 0.00275 & $1,885.79$ & 144.46 & 0.36 \\
\hline 5.5 & 13,700 & 288.33 & 308.95 & 0.00272 & $1,882.96$ & 144.36 & 0.36 \\
\hline 5.5 & 13,600 & 288.33 & 308.93 & 0.00269 & $1,880.21$ & 144.27 & 0.35 \\
\hline 5.5 & 13,500 & 288.33 & 308.91 & 0.00266 & $1,877.49$ & 144.19 & 0.35 \\
\hline 5 & 14,500 & 288.33 & 308.43 & 0.00252 & $1,505.33$ & 111.13 & 0.43 \\
\hline 5 & 14,400 & 288.33 & 308.42 & 0.00249 & $1,504.00$ & 110.93 & 0.43 \\
\hline 5 & 14,300 & 288.33 & 308.41 & 0.00246 & $1,502.71$ & 110.74 & 0.42 \\
\hline 5 & 14,200 & 288.33 & 308.40 & 0.00243 & $1,501.45$ & 110.56 & 0.42 \\
\hline 5 & 14,100 & 288.33 & 308.39 & 0.00241 & $1,500.23$ & 110.38 & 0.42 \\
\hline 5 & 14,000 & 288.33 & 308.38 & 0.00238 & $1,499.04$ & 110.20 & 0.42 \\
\hline 5 & 13,900 & 288.33 & 308.36 & 0.00235 & $1,497.89$ & 110.03 & 0.41 \\
\hline 5 & 13,800 & 288.33 & 308.35 & 0.00232 & $1,496.77$ & 109.87 & 0.41 \\
\hline 5 & 13,700 & 288.33 & 308.34 & 0.00229 & $1,495.67$ & 109.70 & 0.41 \\
\hline 5 & 13,600 & 288.33 & 308.33 & 0.00226 & $1,494.61$ & 109.55 & 0.41 \\
\hline 5 & 13,500 & 288.33 & 308.33 & 0.00223 & $1,493.58$ & 109.39 & 0.40 \\
\hline 4.7 & 14,500 & 287.48 & 308.49 & 0.00172 & $1,725.49$ & 124.84 & 0.40 \\
\hline 4.7 & 14,400 & 287.48 & 308.48 & 0.00170 & $1,723.86$ & 124.79 & 0.40 \\
\hline 4.7 & 14,300 & 287.48 & 308.47 & 0.00168 & $1,722.27$ & 124.75 & 0.39 \\
\hline 4.7 & 14,200 & 287.48 & 308.45 & 0.00166 & $1,720.73$ & 124.71 & 0.39 \\
\hline 4.7 & 14,100 & 287.48 & 308.44 & 0.00165 & $1,719.23$ & 124.67 & 0.39 \\
\hline 4.7 & 14,000 & 287.48 & 308.43 & 0.00163 & $1,717.77$ & 124.63 & 0.39 \\
\hline 4.7 & 13,900 & 287.48 & 308.42 & 0.00161 & $1,716.34$ & 124.59 & 0.38 \\
\hline 4.7 & 13,800 & 287.48 & 308.41 & 0.00159 & $1,714.95$ & 124.56 & 0.38 \\
\hline 4.7 & 13,700 & 287.48 & 308.40 & 0.00157 & $1,713.59$ & 124.52 & 0.38 \\
\hline 4.7 & 13,600 & 287.48 & 308.39 & 0.00155 & $1,712.27$ & 124.48 & 0.38 \\
\hline 4.7 & 13,500 & 287.48 & 308.37 & 0.00153 & $1,710.98$ & 124.45 & 0.38 \\
\hline 4.5 & Bridge & & & & & & \\
\hline
\end{tabular}


Table 1-3. HEC-RAS model calibration to estimate the April 2007 Suncook River flood-peak discharge from high-water-mark data collected at the Short Falls Road bridge in Epsom, New Hampshire.-Continued

[River station locations are indicated by an arbitrary cross-section numbering system and are not shown on any figure. $\mathrm{ft}$, feet; $\mathrm{ft}^{3} / \mathrm{s}$, cubic feet per second]

\begin{tabular}{|c|c|c|c|c|c|c|c|}
\hline River station & $\begin{array}{c}\text { Q, total } \\
\text { discharge } \\
\left(\mathrm{ft}^{3} / \mathrm{s}\right)\end{array}$ & $\begin{array}{l}\text { Minimum } \\
\text { channel } \\
\text { elevation } \\
\text { (ft) }\end{array}$ & $\begin{array}{c}\text { Water-surface } \\
\text { elevation } \\
\text { (ft) }\end{array}$ & $\begin{array}{c}\text { Energy grade } \\
\text { slope } \\
\text { (ft/ft) }\end{array}$ & $\begin{array}{c}\text { Flow area } \\
\left(\mathrm{ft}^{2}\right)\end{array}$ & $\begin{array}{l}\text { Top width } \\
\text { (ft) }\end{array}$ & $\begin{array}{l}\text { Channel } \\
\text { Froude } \\
\text { number }\end{array}$ \\
\hline 4.3 & 14,500 & 287.48 & 307.48 & 0.00210 & $1,601.24$ & 120.77 & 0.44 \\
\hline 4.3 & 14,400 & 287.48 & 307.49 & 0.00207 & $1,602.19$ & 120.82 & 0.43 \\
\hline 4.3 & 14,300 & 287.48 & 307.50 & 0.00204 & $1,603.12$ & 120.86 & 0.43 \\
\hline 4.3 & 14,200 & 287.48 & 307.50 & 0.00201 & $1,604.05$ & 120.91 & 0.43 \\
\hline 4.3 & 14,100 & 287.48 & 307.51 & 0.00198 & $1,604.97$ & 120.96 & 0.43 \\
\hline 4.3 & 14,000 & 287.48 & 307.52 & 0.00195 & $1,605.89$ & 121.00 & 0.42 \\
\hline 4.3 & 13,900 & 287.48 & 307.53 & 0.00192 & $1,606.79$ & 121.05 & 0.42 \\
\hline 4.3 & 13,800 & 287.48 & 307.53 & 0.00189 & $1,607.69$ & 121.09 & 0.42 \\
\hline 4.3 & 13,700 & 287.48 & 307.54 & 0.00186 & $1,608.57$ & 121.14 & 0.41 \\
\hline 4.3 & 13,600 & 287.48 & 307.55 & 0.00183 & $1,609.45$ & 121.18 & 0.41 \\
\hline 4.3 & 13,500 & 287.48 & 307.56 & 0.00180 & $1,610.32$ & 121.22 & 0.41 \\
\hline 4 & 14,500 & 286.73 & 307.99 & 0.00032 & $4,897.13$ & 385.23 & 0.16 \\
\hline 4 & 14,400 & 286.73 & 307.99 & 0.00031 & $4,897.21$ & 385.23 & 0.16 \\
\hline 4 & 14,300 & 286.73 & 307.99 & 0.00031 & $4,897.29$ & 385.23 & 0.16 \\
\hline 4 & 14,200 & 286.73 & 307.99 & 0.00031 & $4,897.37$ & 385.24 & 0.16 \\
\hline 4 & 14,100 & 286.73 & 307.99 & 0.00030 & $4,897.45$ & 385.24 & 0.15 \\
\hline 4 & 14,000 & 286.73 & 307.99 & 0.00030 & $4,897.53$ & 385.24 & 0.15 \\
\hline 4 & 13,900 & 286.73 & 307.99 & 0.00029 & $4,897.60$ & 385.24 & 0.15 \\
\hline 4 & 13,800 & 286.73 & 307.99 & 0.00029 & $4,897.69$ & 385.25 & 0.15 \\
\hline 4 & 13,700 & 286.73 & 307.99 & 0.00028 & $4,897.76$ & 385.25 & 0.15 \\
\hline 4 & 13,600 & 286.73 & 307.99 & 0.00028 & $4,897.84$ & 385.25 & 0.15 \\
\hline 4 & 13,500 & 286.73 & 307.99 & 0.00028 & $4,897.91$ & 385.26 & 0.15 \\
\hline 3 & 14,500 & 276.83 & 308.05 & 0.000063 & $9,822.06$ & 631.09 & 0.09 \\
\hline 3 & 14,400 & 276.83 & 308.05 & 0.000063 & $9,821.64$ & 631.08 & 0.09 \\
\hline 3 & 14,300 & 276.83 & 308.05 & 0.000062 & $9,821.20$ & 631.06 & 0.09 \\
\hline 3 & 14,200 & 276.83 & 308.05 & 0.000061 & $9,820.77$ & 631.05 & 0.09 \\
\hline 3 & 14,100 & 276.83 & 308.05 & 0.000060 & $9,820.37$ & 631.04 & 0.09 \\
\hline 3 & 14,000 & 276.83 & 308.05 & 0.000059 & $9,819.94$ & 631.03 & 0.09 \\
\hline 3 & 13,900 & 276.83 & 308.05 & 0.000058 & $9,819.52$ & 631.02 & 0.09 \\
\hline 3 & 13,800 & 276.83 & 308.04 & 0.000057 & $9,819.11$ & 631.01 & 0.09 \\
\hline 3 & 13,700 & 276.83 & 308.04 & 0.000057 & $9,818.71$ & 631.00 & 0.08 \\
\hline 3 & 13,600 & 276.83 & 308.04 & 0.000057 & $9,818.31$ & 630.99 & 0.08 \\
\hline 3 & 13,500 & 276.83 & 308.04 & 0.000057 & $9,817.90$ & 630.97 & 0.08 \\
\hline 2 & 14,500 & 270.77 & 308.08 & 0.00002 & $15,316.79$ & 937.35 & 0.05 \\
\hline 2 & 14,400 & 270.77 & 308.08 & 0.00002 & $15,315.73$ & 937.34 & 0.05 \\
\hline 2 & 14,300 & 270.77 & 308.08 & 0.00002 & $15,314.65$ & 937.33 & 0.05 \\
\hline 2 & 14,200 & 270.77 & 308.08 & 0.00002 & $15,313.59$ & 937.32 & 0.05 \\
\hline 2 & 14,100 & 270.77 & 308.08 & 0.00002 & $15,312.56$ & 937.31 & 0.05 \\
\hline 2 & 14,000 & 270.77 & 308.08 & 0.00002 & $15,311.50$ & 937.31 & 0.05 \\
\hline 2 & 13,900 & 270.77 & 308.08 & 0.00002 & $15,310.47$ & 937.30 & 0.05 \\
\hline 2 & 13,800 & 270.77 & 308.08 & 0.00002 & $15,309.44$ & 937.29 & 0.05 \\
\hline 2 & 13,700 & 270.77 & 308.07 & 0.00002 & $15,308.44$ & 937.28 & 0.05 \\
\hline 2 & 13,600 & 270.77 & 308.07 & 0.00002 & $15,307.41$ & 937.27 & 0.05 \\
\hline 2 & 13,500 & 270.77 & 308.07 & 0.00002 & $15,306.41$ & 937.26 & 0.05 \\
\hline
\end{tabular}


Table 1-3. HEC-RAS model calibration to estimate the April 2007 Suncook River flood-peak discharge from high-water-mark data collected at the Short Falls Road bridge in Epsom, New Hampshire.-Continued

[River station locations are indicated by an arbitrary cross-section numbering system and are not shown on any figure. $\mathrm{ft}$, feet; $\mathrm{ft}^{3} / \mathrm{s}$, cubic feet per second]

\begin{tabular}{|c|c|c|c|c|c|c|c|}
\hline River station & $\begin{array}{c}\text { 0, total } \\
\text { discharge } \\
\left(\mathrm{ft}^{3} / \mathrm{s}\right)\end{array}$ & $\begin{array}{l}\text { Minimum } \\
\text { channel } \\
\text { elevation } \\
\text { (ft) }\end{array}$ & $\begin{array}{c}\text { Water-surface } \\
\text { elevation } \\
\text { (ft) }\end{array}$ & $\begin{array}{c}\text { Energy grade } \\
\text { slope } \\
\text { (ft/ft) }\end{array}$ & $\begin{array}{c}\text { Flow area } \\
\left(\mathrm{ft}^{2}\right)\end{array}$ & $\begin{array}{l}\text { Top width } \\
\text { (ft) }\end{array}$ & $\begin{array}{c}\text { Channel } \\
\text { Froude } \\
\text { number }\end{array}$ \\
\hline 1 & 14,500 & 286.21 & 308.00 & 0.00014 & $9,571.49$ & 943.03 & 0.12 \\
\hline 1 & 14,400 & 286.21 & 308.00 & 0.00014 & $9,571.49$ & 943.03 & 0.12 \\
\hline 1 & 14,300 & 286.21 & 308.00 & 0.00014 & $9,571.49$ & 943.03 & 0.12 \\
\hline 1 & 14,200 & 286.21 & 308.00 & 0.00013 & $9,571.49$ & 943.03 & 0.12 \\
\hline 1 & 14,100 & 286.21 & 308.00 & 0.00013 & $9,571.49$ & 943.03 & 0.12 \\
\hline 1 & 14,000 & 286.21 & 308.00 & 0.00013 & $9,571.49$ & 943.03 & 0.12 \\
\hline 1 & 13,900 & 286.21 & 308.00 & 0.00013 & $9,571.49$ & 943.03 & 0.12 \\
\hline 1 & 13,800 & 286.21 & 308.00 & 0.00013 & $9,571.49$ & 943.03 & 0.12 \\
\hline 1 & 13,700 & 286.21 & 308.00 & 0.00012 & $9,571.49$ & 943.03 & 0.12 \\
\hline 1 & 13,600 & 286.21 & 308.00 & 0.00012 & $9,571.49$ & 943.03 & 0.12 \\
\hline 1 & 13,500 & 286.21 & 308.00 & 0.00012 & $9,571.49$ & 943.03 & 0.11 \\
\hline
\end{tabular}


Table 1-4. HEC-RAS model calibration to estimate the April 2007 Suncook River flood-peak discharge from high-water-mark data collected at the Websters Mill Road bridge in Chichester/Pittsfield, New Hampshire.

[River station locations are indicated by an arbitrary cross-section numbering system and are not shown on any figure. $\mathrm{ft}$, feet; $\mathrm{ft}^{3} / \mathrm{s}$, cubic feet per second]

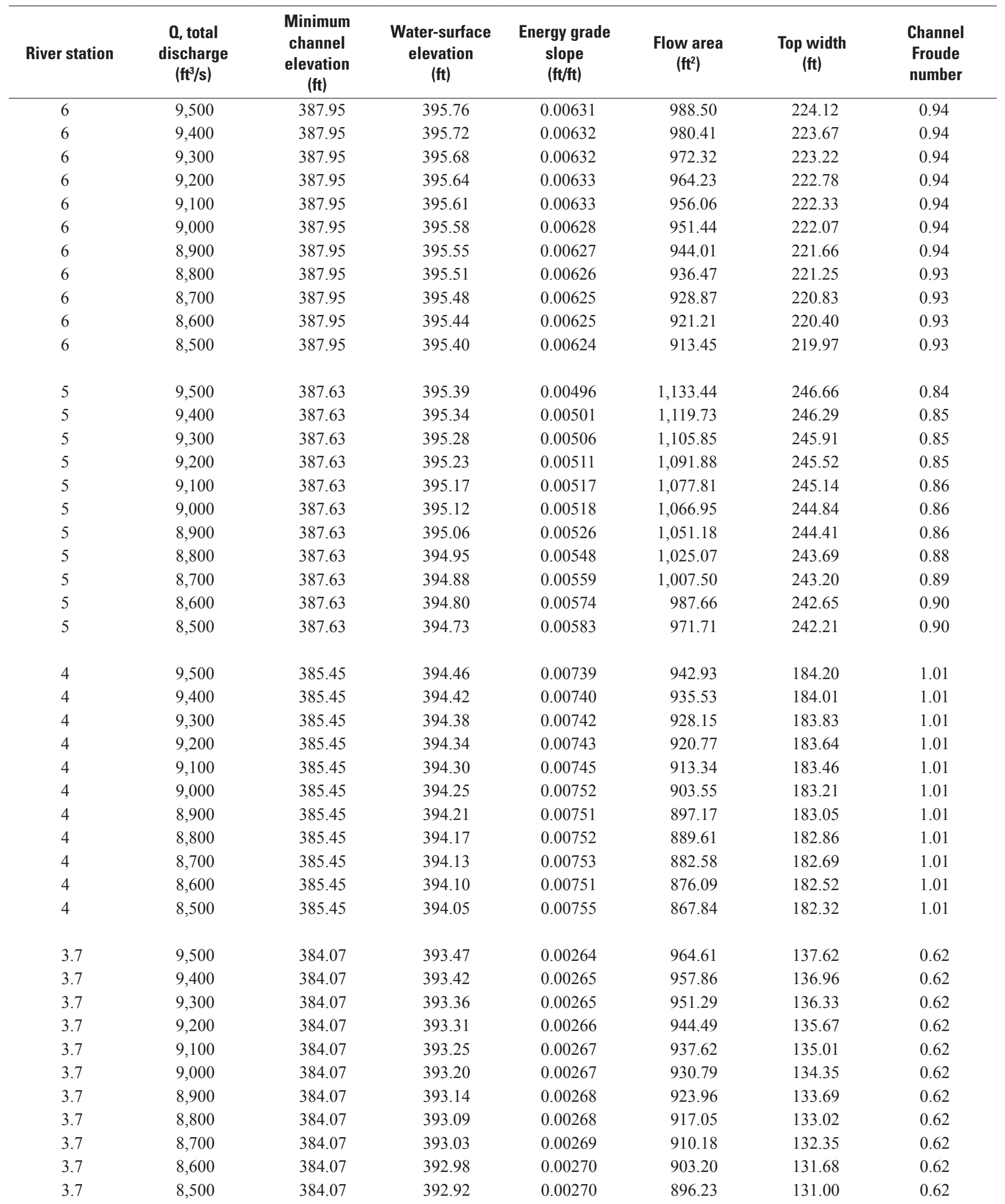


Table 1-4. HEC-RAS model calibration to estimate the April 2007 Suncook River flood-peak discharge from high-water-mark data collected at the Websters Mill Road bridge in Chichester/Pittsfield, New Hampshire.-Continued

[River station locations are indicated by an arbitrary cross-section numbering system and are not shown on any figure. $\mathrm{ft}$, feet; $\mathrm{ft}^{3} / \mathrm{s}$, cubic feet per second]

\begin{tabular}{|c|c|c|c|c|c|c|c|}
\hline River station & $\begin{array}{c}\text { 0, total } \\
\text { discharge } \\
\left(\mathrm{ft}^{3} / \mathrm{s}\right)\end{array}$ & $\begin{array}{l}\text { Minimum } \\
\text { channel } \\
\text { elevation } \\
\text { (ft) }\end{array}$ & $\begin{array}{l}\text { Water-surface } \\
\text { elevation } \\
\text { (ft) }\end{array}$ & $\begin{array}{l}\text { Energy grade } \\
\text { slope } \\
\text { (ft/ft) }\end{array}$ & $\begin{array}{l}\text { Flow area } \\
\left(\mathrm{ft}^{2}\right)\end{array}$ & $\begin{array}{l}\text { Top width } \\
\text { (ft) }\end{array}$ & $\begin{array}{l}\text { Channel } \\
\text { Froude } \\
\text { number }\end{array}$ \\
\hline 3.5 & Bridge & & & & & & \\
\hline 3.2 & 9,500 & 384.07 & 391.82 & 0.00558 & 767.08 & 127.89 & 0.87 \\
\hline 3.2 & 9,400 & 384.07 & 391.78 & 0.00559 & 761.65 & 127.79 & 0.87 \\
\hline 3.2 & 9,300 & 384.07 & 391.73 & 0.00562 & 755.17 & 127.66 & 0.88 \\
\hline 3.2 & 9,200 & 384.07 & 391.67 & 0.00565 & 748.92 & 127.53 & 0.88 \\
\hline 3.2 & 9,100 & 384.07 & 391.63 & 0.00567 & 743.12 & 127.41 & 0.88 \\
\hline 3.2 & 9,000 & 384.07 & 391.58 & 0.00570 & 736.80 & 127.29 & 0.88 \\
\hline 3.2 & 8,900 & 384.07 & 391.56 & 0.00562 & 734.79 & 127.25 & 0.87 \\
\hline 3.2 & 8,800 & 384.07 & 391.51 & 0.00566 & 728.28 & 127.12 & 0.87 \\
\hline 3.2 & 8,700 & 384.07 & 391.45 & 0.00570 & 721.64 & 126.98 & 0.88 \\
\hline 3.2 & 8,600 & 384.07 & 391.40 & 0.00573 & 715.00 & 126.85 & 0.88 \\
\hline 3.2 & 8,500 & 384.07 & 391.35 & 0.00576 & 708.66 & 126.72 & 0.88 \\
\hline 3 & 9,400 & 381.86 & 391.91 & 0.00210 & $1,112.27$ & 151.73 & 0.55 \\
\hline 3 & 9,300 & 381.86 & 391.86 & 0.00211 & $1,103.75$ & 151.49 & 0.55 \\
\hline 3 & 9,200 & 381.86 & 391.80 & 0.00211 & $1,095.52$ & 151.26 & 0.55 \\
\hline 3 & 9,100 & 381.86 & 391.75 & 0.00211 & $1,087.83$ & 151.05 & 0.55 \\
\hline 3 & 9,000 & 381.86 & 391.70 & 0.00211 & $1,079.53$ & 150.82 & 0.55 \\
\hline 3 & 8,900 & 381.86 & 391.68 & 0.00208 & $1,076.52$ & 150.74 & 0.55 \\
\hline 3 & 8,800 & 381.86 & 391.62 & 0.00208 & $1,067.98$ & 150.50 & 0.55 \\
\hline 3 & 8,700 & 381.86 & 391.56 & 0.00209 & $1,059.29$ & 150.26 & 0.55 \\
\hline 3 & 8,600 & 381.86 & 391.50 & 0.00209 & $1,050.62$ & 150.02 & 0.55 \\
\hline 3 & 8,500 & 381.86 & 391.45 & 0.00209 & $1,042.31$ & 149.79 & 0.54 \\
\hline 2 & 9,500 & 381.20 & 389.07 & 0.01078 & 858.68 & 220.06 & 0.93 \\
\hline 2 & 9,400 & 381.20 & 389.01 & 0.01088 & 849.29 & 219.86 & 0.94 \\
\hline 2 & 9,300 & 381.20 & 388.98 & 0.01082 & 844.65 & 219.76 & 0.93 \\
\hline 2 & 9,200 & 381.20 & 388.94 & 0.01079 & 838.84 & 219.64 & 0.93 \\
\hline 2 & 9,100 & 381.20 & 388.89 & 0.01084 & 830.78 & 219.46 & 0.93 \\
\hline 2 & 9,000 & 381.20 & 388.86 & 0.01081 & 825.01 & 219.34 & 0.93 \\
\hline 2 & 8,900 & 381.20 & 388.67 & 0.01165 & 795.84 & 215.51 & 0.96 \\
\hline 2 & 8,800 & 381.20 & 388.63 & 0.01167 & 788.71 & 214.23 & 0.96 \\
\hline 2 & 8,700 & 381.20 & 388.58 & 0.01167 & 782.00 & 213.02 & 0.96 \\
\hline 2 & 8,600 & 381.20 & 388.54 & 0.01168 & 775.15 & 211.77 & 0.96 \\
\hline 2 & 8,500 & 381.20 & 388.49 & 0.01175 & 766.75 & 210.25 & 0.96 \\
\hline 1 & 9,500 & 376.99 & 383.37 & 0.00598 & $1,089.92$ & 241.65 & 0.67 \\
\hline 1 & 9,400 & 376.99 & 383.37 & 0.00585 & $1,089.92$ & 241.65 & 0.66 \\
\hline 1 & 9,300 & 376.99 & 383.37 & 0.00573 & $1,089.92$ & 241.65 & 0.65 \\
\hline 1 & 9,200 & 376.99 & 383.37 & 0.00561 & $1,089.92$ & 241.65 & 0.65 \\
\hline 1 & 9,100 & 376.99 & 383.37 & 0.00549 & $1,089.92$ & 241.65 & 0.64 \\
\hline 1 & 9,000 & 376.99 & 383.37 & 0.00537 & $1,089.92$ & 241.65 & 0.63 \\
\hline 1 & 8,900 & 376.99 & 383.37 & 0.00525 & $1,089.92$ & 241.65 & 0.63 \\
\hline 1 & 8,800 & 376.99 & 383.37 & 0.00513 & $1,089.92$ & 241.65 & 0.62 \\
\hline 1 & 8,700 & 376.99 & 383.37 & 0.00501 & $1,089.92$ & 241.65 & 0.61 \\
\hline 1 & 8,600 & 376.99 & 383.37 & 0.00490 & $1,089.92$ & 241.65 & 0.60 \\
\hline 1 & 8,500 & 376.99 & 383.37 & 0.00479 & $1,089.92$ & 241.65 & 0.60 \\
\hline
\end{tabular}

